\title{
Isabel la Católica, fiel hija de la Iglesia, y la hispanidad
}

\author{
SEGÚN LA FORMÓ MARTÍN DE CÓRDOBA PARA SER \\ REINA DE ESPAÑA
}

\section{Introducción}

Aunque se ha escrito mucho sobre Isabel la Católica, existen aún lagunas y facetas de su vida que no se han clarificado bien, como la fecha exacta de su bautismo en Madrigal y que fue fiel hija de la Iglesia, en una época conflictiva. No se puede comprender lo que significaba en la Edad Media ser fiel hija de la Iglesia, si no se tiene en cuenta el concepto de ser cristiano y miembro de la Cristiandad medieval, en la que se formó Isabel la Católica. Se preparó para ser reina según las orientaciones de sus formadores, uno de los principales fue fray Martín de Córdoba, agustino. Se hizo esto conforme a las ideas de la Cristiandad y las características del llamado "Agustinismo Político", de la caballerosidad cristiana, etc. Se hace aquí también una reflexión sobre su vida, indigenismo, testamento y proceso.

La primera vez que hice una investigación sobre los Reyes Católicos fue en 1970 con motivo de un trabajo práctico realizado en la Universidad Pontificia de Salamanca bajo la dirección del entonces profesor de Derecho Concordatario y actualmente cardenal Dr. Antonio $\mathrm{M}^{\mathrm{a}}$ Rouco Varela sobre la relación de Isabel y Fernando con la Santa Sede a través de la documentación de los colectores y legados pontificios, especialmente del primer nuncio permanente en España, el valenciano D. Francisco de Prat (1492-1503)1.

1. Fernández Alonso, Justo, "Don Francisco de Prat, primer Nuncio permanente en España (1492-1503)", Anthologica Annua (1953) 67-154; Legaciones y nunciaturas en España de 1466 a 1521, I, 1466-1486. Roma 1963; Rouco VARELA, Antonio María, Staat und Kirche im Spanien des 16 Jahrhunderts, Munich 1965. Aquí se usa la traducción realizada por SzuMLAKOWSKI MoRODo, Irene, Estado e Iglesia en la España del siglo XVI, Madrid 2001, donde se men- 
Posteriormente volví a profundizar en el tema con motivo de una conferencia dada el 26 de noviembre de 1997, a petición de los Caballeros de la Hispanidad para recordar el 493 aniversario de su muerte en Medina del Campo. Esto me obligó a leer algunos libros y a reflexionar sobre la Hispanidad, formación de Isabel la Católica, sus ideas o ideario según la Cristiandad medieval, sus virtudes, su actitud indigenista, etc. La relectura de su Testamento y Codicilo me entusiasmó, especialmente la Oración fúnebre pronunciada, en 1904, por el P. Zacarías Martínez Núñez, agustino, entonces Director del Real Colegio Alfonso XIII de El Escorial. Él fue uno de los primeros que insinuó la posibilidad de iniciar el proceso de canonización de Isabel la Católica, a la que consideraba una santa y esperaba se hiciese para el 2004, "el panegírico de una Reina Santa que nació en Madrigal y murió en Medina del Campo"2. Ya D. Modesto Lafuente se sorprendía a mediados del siglo XIX de que no se hallase "en la nómina de los escogidos"3. Recordé en 1997 que en 1992, al estudiar la advocación mariana de Nuestra Señora de la $O$ de Otengá (Cundinamarca, Colombia), pude comprobar que se le daba algo de culto en un cuadro de Nuestra Señora de los Dolores de la Santísima Virgen, porque tiene la cara de Isabel la Católica, a la que hacían peticiones los de Otengá y obtenían favores o gracias. Coincide este cuadro con una pintura anónima de finales del siglo XV, que aparece en la Enciclopedia Espasa y pertenece a la Colección Lázaro Galdeano, en Madrid4. Como se le daba indirectamente algo de culto podía incidir en el proceso de canonización.

$\mathrm{Al}$ asistir el 22 de abril de 2001 a los actos que se celebraban en Madrigal de las Altas Torres con motivo del 550 aniversario del nacimiento de Isabel, el buen amigo y Gran Canciller de los Caballeros de Isabel la Católica, Excmo. Sr. D. Alfredo Silva Almeida, me pidió que estudiase el tema de Isabel fiel hija de la Iglesia. Me comprometí después de pensarlo, sabiendo que es un tema muy complejo y difícil. Me sentí obligado al ser nombrado miembro de la Academia de la Hispanidad el 16 de marzo de 2002. Algo

40 veces a Isabel la Católica. En 1970 hice el trabajo de seminario sobre "El primer nuncio permanente, la inquisición y el patronato en tiempo de los Reyes Católicos", mecanografiado en 8 folios, que me han servido de base para una parte de este trabajo. Se dio una charla sobre esto el día 6 de noviembre de 2003 en la Caja Círculo Católico de Valladolid.

2. MARTínez, Zacarías, Oración fúnebre con motivo del cuarto centenario de la muerte de Isabel la Católica, Madrid 1904, pp. 8 y 65.

3. LAFUENTE, Modesto, Historia General de España, VIII, Introducción a la Edad Moderna, Barcelona 1889, pp. 23-24.

4. Enciclopedia Espasa, vol 28, Barcelona 1925, p. 2017. Sobre esto he publicado dos artículos: "Isabel la Católica y Nuestra Señora de la $O$ ", Isabel, revista internacional de la sierva de Dios, n. 25, enero-febrero del 2000, pp. 3-4 y "Nuestra Señora de la O de Otengá ", en Iconografía Agustiniana, Instituto Histórico Agustiniano, Roma, 2001, pp. 610-612. 
nuevo podía añadir, porque conocía la doctrina canónica y teológica sobre esta materia, especialmente sobre la potestad eclesiástica de fray Martín de Córdoba, uno de sus formadores 5 .

Se va a exponer cómo Isabel fue hija espiritual de la Iglesia primero en su bautismo y en su formación como princesa, luego como reina y finalmente en su testamento y muerte con su proyección en la Hispanidad. Aunque no se tiene noticia documental de su bautismo, se supone que fue bautizada cuanto antes, es decir, dentro de los ocho primeros días de su nacimiento, como era costumbre en España y se estableció en algunos sínodos. A veces se retrasaba hasta 15 días. Debió de hacerse, como estaba mandado en la pila bautismal de la parroquia de San Nicolás, aunque los reyes y príncipes podían ser bautizados en el palacio. Se podía hacer también en una casa particular sólo en caso de necesidad y peligro de muerte o cuando se tenía permiso del obispo ${ }^{6}$. Su hermano Enrique fue bautizado en Valladolid a los 8 días después de haber nacido, por el obispo de Cuenca, D. Álvaro de Isorno, con tres padrinos y tres madrinas?

Consta documentalmente que Isabel I de Castilla nació en Madrigal el 22 de abril de 1451, fiesta de jueves santo, a las cuatro horas y dos tercios, después de mediodía, es decir, las 4,45 de la tarde. Su madre se llamaba Isabel de Aviz o de Portugal, segunda esposa de D. Juan II de Castilla ${ }^{8}$. Este matrimonio había sido auspiciado por el condestable D. Alvaro de Luna, que cayó en desgracia para Isabel de Portugal. Juan II fue un rey débil de carácter y dependiente de sus validos, pero al mismo tiempo mecenas de las artes, de las

5. CAMPo DEL Pozo, Fernando, "Opúsculo sobre la potestad eclesiástica de Martín de Córdoba", La Ciudad de Dios, 208 (1995).661-694. Martín de Córdoba era amigo del rey D. Juan, de su hijo Alfonso y de D. Enrique, que quiso retenerlo en la corte, como lo fue también de Isabel de Portugal y de su hija.

6. Clemente V, Clementinas, libro III, título XV, capítulo único. De baptismo, donde se recoge una Constitución del Concilio de Viena de 1312. FrIEDBERG, Aemilius, Corpus Iuris, 2 ed., II, Graz 1959, col. 1174.

7. VAL, Isabel del, Ísabel la Católica princesa (1468-1474), Valladolid 1974, p. 33. Enrique nació en Valladolid el 5 de enero de 1425 y fue bautizado el día 13. Fueron sus padrinos el almirante D. Alonso Enríquez, el condestable D. Álvaro de Luna y D. Diego Gómez de Sandoval, adelantado mayor de Castilla. Fueron madrinas $D^{a}$ Juana Mendoza, esposa del almirante, la esposa del condestable $D^{a}$ Elvira Portocarrero y la esposa del adelantado $D^{a}$ Beatriz de Avellaneda.

8. Dr. Toledo, médico de la Reina Católica, Cronicón de Valladolid, ilustrado por Pedro Sáinz de Baranda, edic. facsímil, Valladolid 1981, p. 20. Esto fue bien estudiado por ClemENCín, Diego de, Ilustraciones sobre varios asuntos del reinado de Isabel la Católica, I, Madrid 1821, pp. 56-60. Cf. TORRES FonTES, Juan, Estampas de la vida murciana durante el reinado de los Reyes Católicos, I, Murcia 1960. Isabel se parecía a su bisabuela Felipa de Lancáster con pelo rubio y rojizo. 
letras, de la filosofía y de la historia. No sabía ejercer la autoridad, ni hacer la guerra para reconquistar tierras a los moros; pero preparó el ambiente "para el porvenir de letras y ciencias más brillante y duradera gloria"9. El nacimiento de Isabel la Católica fue dado a conocer oficialmente por Juan II desde la Villa de Madrid a todo el Reino de Castilla y de León, que recibió con alegría la noticia. En algunas ciudades, como en Burgos, se celebró con especial júbilo, según consta en sesión del cabildo del 30 de abril de 1451 , entregando al portador de las cartas la cantidad de 500 maravadíes a propuesta del canónigo Íñigo de Mendoza ${ }^{10}$. No hay constancia oficial de la fecha de su bautismo, aunque sí del hecho. Fue bautizada probablemente el 30 de abril de 1451 con el nombre de Isabel, cuyo nombre fue propuesto por D. Gonzalo Chacón, mayordomo de la reina, que se encargó de buscar padrinos y madrinas, entre las que propuso a su esposa $D^{a}$ Clara Alvarnáez, según refiere la tradición recogida por Ángeles de Irisarri, que afirma que se "la llevó a bautizar a la iglesia de San Nicolás de Bari"11.

Entre los formadores de su infancia hay que mencionar a $\mathrm{D}^{\mathrm{a}}$ Beatriz de Silva, portuguesa ${ }^{12}$ y luego cofundadora de las Concepcionistas franciscanas, a las que regaló, siendo reina, los palacios de Galiana en Toledo. Los tres primeros años, los pasó Isabel, al igual que su hermano Alfonso, en el ambiente de la corte hasta la muerte de Juan II en julio de 1454. Su padre la dejó para su manutención la villa de Cuéllar con sus rentas y se añadiría la de Madrigal, cuando muriera su madre. Debía recibir además desde que cumpliese diez años hasta que contrajese matrimonio la renta anual de un millón de maravedíes, descontando lo que produjesen las rentas de Cuéllar y en su momento las de Madrigal. Al contraer matrimonio, Cuéllar y Madrigal pasaban de nuevo a la corona. Juan II estableció una tutoría para los infantes Alfonso e Isabel, presidida por Lope de Barrientos y Juan de Padilla, con derecho a fijar su residencia ${ }^{13}$, que hasta la edad de 10 años transcurrió entre Arévalo y Madrigal, con alguna visita a Medina del Campo.

Isabel de Portugal enferma de incurable tristeza y con síntomas de locura, sé recluyó en Arévalo, sin perder su responsabilidad en la educación moral de la princesa, como buena cristiana, la procuró excelentes consejeros y ense-

9. Ríos, Amador de los, Historia crítica de la Literatura Española, VI, Madrid 1865, p. 8.

10. Serrano, Luciano, Los Reyes Católicos y la ciudad de Burgos, Madrid 1943, p. 9.

11. IRISARRI, Ángeles de, Isabel, Reina, Barcelona 2001, p. 24. En la capilla de la pila de bautizar de San Nicolás hay una inscripción del siglo pasado recordando este hecho.

12. SUÁREZ FERNÁNDEZ, Luis, Isabel, mujer y reina, Madrid 1992, p. 12,

13. Memorias de don Enrique IV de Castilla, tomo II, Colección diplomática compuesta y ordenada por la Real Academia de la Historia, XLVI, Madrid 1835-1913, pp. 116-117. Cf. VAL, Isabel del, Isabel la Católica, princesa (1468-1474), p. 38. 
ñarla, ante todas las cosas, el amor a Dios y el respeto profundo a la santa Madre Iglesia. Entre los formadores desempeñó un papel importante el agustino fray Martín de Córdoba, que había sido amigo de D. Álvaro de Luna. Tomaron parte también los franciscanos del convento Arévalo, como fray Llorente y otros eclesiásticos ${ }^{14}$.

A la edad de 11 años, en una época de bandos nobiliarios y de intrigas, fue llevada a la corte de su hermanastro Enrique IV, "el impotente" para que amadrinase a Juana, la "Beltraneja", y prestase juramento de obediencia a las Cortes, que habían sido convocadas para reconocer a la Beltraneja como heredera del trono. Fue llamada de nuevo a la Corte, al año siguiente, cuando cumplía los doce años, junto con su hermano Alfonso con pretexto de completar su educación y de iniciarles en la vida palaciega, aunque la razón era, en realidad, apartarles de Arévalo. Se trataba de un tránsito peligroso en la Corte por los escándalos que allí había. Podía interrumpirse y peligrar la formación recibida en Arévalo, por cuyo castillo deambulaba Isabel de Portugal evocando al condestable Don Álvaro de Luna, que había sido ejecutado en Valladolid, en 1453, sin un proceso legal, por sus intrigas, como descargo de su conciencia. Fue entonces cuando intervino providencialmente su mejor formador, fray Martín de Córdoba, que se había graduado en Tolosa y estaba de catedrático en la universidad de Salamanca en 1451. Volvió a Tolosa, como profesor en 1461. En 1465 y 1468 presidió los capítulos provinciales de Castilla y se relacionó con la corte de Enrique IV, como lo había hecho anteriormente con D. Álvaro de Luna y Juan II. Siguió asesorando a Isabel de Portugal en Arévalo que le encargó la educación de su hijo Alfonso y de Isabel. En el libro Jardín de Nobles Doncellas, se menciona ya la muerte del Príncipe Alfonso (5 de junio de 1468) por lo que la dedicatoria es posterior a esa fecha, probablemente el 22 de abril de 1469, y antes de octubre de 1469. Martín de Córdoba asesoró a Isabel de un modo especial entre los 15 y los 17 años. Se puede considerar este libro como un regalo en sus 16 años con esta dedicatoria: "a la muy clara y serenísima señora, doña Isabel, de real simiente procreada, infanta legítima heredera de los reinos de Castilla y León"15. Le puso como modelo a la Santísima Virgen. Ella lo conservó como una guía y joya.

14. SuÁreZ, Luis, Isabel I, Reina, Madrid 2004, p. 16, donde se da la bliografía fundamental sobre esta época en las notas de esta edición aparecida en Biblioteca ABC

15. CóRDOBA, Martín de, Jardín de Nobles Doncellas, edic. por P. Félix García, Madrid 1956, poemio, p. 69. En la p. 74 se menciona la muerte de Alfonso, su hermano. La primera edición se hizo en Valladolid en los talleres de Juan de Burgos en 1500. En $4^{\circ}$ got., 64 p. con 28 líneas. Se conserva un ejemplar en la Biblioteca de la Sociedad Hispánica de Nueva York. La segunda edi- 
No cabe la menor duda de que Martín de Córdoba asesoró a Isabel durante las deliberaciones que mantuvo desde el Pacto de Guisando, 18 de septiembre de 1468, hasta las capitulaciones matrimoniales con Fernando de Aragón el 7 de enero de 1469. Quizás algún día aparezcan más cartas de las que escribió haciendo consultas, como la que hizo a primeros de enero de 1469 al nuncio o legado pontificio Antonio Jacobo de Veneris o de Veniero en Ocaña. Ella supo esperar y acatar las disposiciones de las autoridades eclesiásticas, como el legado Veneris y el arzobispo de Toledo, Alfonso Carrillo, pudiendo afirmar en la respuesta a su hermano Enrique y al cardenal de Albi, Juan Joufroy, embajador de Francia y Señor de Malicorne, que "tenía bien saneada su conciencia" y tranquila ${ }^{16}$. Sabía ser buena y fiel hija de la Iglesia. Se margina aquí el tema de su matrimonio celebrado en Valladolid el 19 de octubre de 1469 y la dispensa del impedimento de tercer grado de consanguinidad, por ser un tema ampliamente estudiado y aclarado ${ }^{17}$.

Para comprender lo que significaba para Isabel ser hija de la Iglesia, conviene tratar el concepto de Cristiandad medieval en que se formó, la cultura del medio ambiente y lo que significaba ser cristiano, con una religiosidad unida a la caballerosidad. Algo se ha esbozado incidentalmente por algunos autores como luego veremos. De su religiosidad ha tratado indirectamente D. Vicente Rodríguez Valencia al exponer sus virtudes y santidad ${ }^{18}$. D. Vidal

ción se hizo en Medina del Campo en 1542 por Juan de Espinosa, mercader de libros. Se encuentra un ejemplar en la Biblioteca Nacional de Madrid, R. 9717, en cuarto, letra gótica, cuarenta y ocho hs., signatura A-F. De ésta hay una edición facsímil en 1953 de 250 ejemplares en la Colección Joyas Bibliográficas para bibliófilos. Es mencionada la edición de Medina del Campo por Antonio, Nicolás, Bibliotheca Hispana Vetus, tomo II, Madrid 1672, p. 307, como Vergel de Nobles Doncellas, con esta dedicatoria: Ad Elisabetham tunc Infantem. Henrici IV sororem, nondum, ut credimus, regnauguratam. Hay una edición facsímil hecha en Madrid 1996, II, p. 304, n. 664. de la traducción castellana por Benito Fidel Aguilar, Madrid 1788.- Lo mencionan como Vergel san Alonso de Orozco y el P. Portillo. Cf. GARCÍA, Félix. "prólogo", p. 45. Este autor utilizó la edición hecha en Medina del Campo para la de 1956, en Religión y Cultura, con una ortografía modernizada. El P. Manuel Vidal cita la obra como "Huerto de Nobles Doncellas" y el P. Antonio Possevino, S.J. como "Huerto de las Doncellas Nobles". Ha sido publicado el Jardín de Nobles Doncellas por el P. Fernando Rubio en Biblioteca de Autores Españoles, Colección Rivadeneira, vol 171, Madrid 1964, pp. 67-117. Luis Suárez afirma que "se lo entregó, precioso regalo, el 22 de abril de 1467, cuando cumplía dieciséis años y había tenido sus primeras experiencias políticas". Ella lo conservaba "como una joya". SUÁREZ, Luis, Isabel I, Reina, pp. 16 y 367.

16. Rodríguez VAlencia, Vicente. Artículos del postulador sobre la fama de santidad, vida y virtudes, etc. art. 14, Valladolid 1972, p. 13.

17. MASEguer Fernández, Juan, "La dispensa del impedimento de consanguinida en la boda de los Reyes Católicos", en Archivo Iberoamericano, vol. (1967) 351-354. Cf. VAL, Isabel del, Isabel la Católica princesa, pp. 184-199.

18. Rodríguez Valencia, Vicente, Perfil moral de Isabel la Católica, Valladolid 1974, pp. $203-214$ y $224-226$. 
González Sánchez, entre otros, ha tratado de su perfil moral y su fama de santidad $^{19}$. Después de ver la estructura de la sociedad medieval trataremos de su ideario indigenista y su testamento, que hizo como fiel hija de la Iglesia. Su ideario ha dado origen a lo que se ha llamado Hispanidad. Al final se expone algo sobre su muerte cristiana y ejemplar, el duelo en sus reinos, los cuadros de la Virgen con su cara y el estado de su proceso de canonización.

\section{Concepto de Cristiandad medieval y la religiosidad del caballero cristiano}

Isabel se hizo hija de la Iglesia y de Dios por el bautismo, como se ha observado anteriormente. ¿Qué significaba esto en aquella época? Según el papa Inocencio III, por medio del bautismo se incorporaba la persona en la estructura de la Cristiandad, que le imprimía el carácter de cristiano con sus derechos y obligaciones ${ }^{20}$. Se consideraba a la persona humana hecha a imagen y semejanza de Dios con unos principios de unidad del género humano, igualdad esencial de todos hombres y necesidad de ayudarse. La mujer tenía sus derechos y obligaciones como hija de Dios y de la Iglesia, pudiendo llegar a ser reina.

En la Edad Media, especialmente durante la Reconquista de España, la religiosidad estaba unida a la caballerosidad, el cristiano tenía que ser un caballero y viceversa. Esto era algo constitutivo de aquella sociedad y no se podía ser de otra manera. Al recibir el bautismo Isabel se hizo cristiana y fiel hija de la Iglesia conforme a la doctrina canónica y teológica de aquella época, en la que predominaba un régimen teocrático, presidido por el papa. Una posición parecida la tenía el súbdito frente al rey o la reina, que lo eran por la gracia de Dios. Ya en el siglo XIII hubo tensiones entre el poder del papa y el rey de Francia, como las hubo en tiempo de los Reyes Católicos, que llegaron a tener varios obispos en la cárcel.

\section{a) Ideas vertebradoras de la Cristiandad medieval}

No se puede comprender el contenido de lo que significaba en el siglo XV ser "hijo de la Iglesia", como se ha observado anteriormente, si no se tiene

19. GonZÁlez SÁNCHEZ, Vidal, Isabel la Católica y su fama de santidad. ¿Mito o realidad? Madrid 1999, pp. 71-87 y 196-201.

20. InOCENCIO III, Decretal Maiores Ecclesiae causas de 1201, Liber X, III, 42,3. FRIEDBERG, Aemilius, Corpus Iuris, II, col. 644-646. Los efectos de pertenencia a la Cristiandad obligaban incluso a los que lo habían recibido ficticiamente: "is qui ficte baptismum ad baptismum accedit, characterem suscipit Cristianitatis impressum et ipse tanquam condicionaliter volens, licet absolute non velit, cogendus est ad observandam fidei christianae". 
una idea clara y distinta de lo que fue la Cristiandad medieval, vertebrada por tres ideas fundamentales: $1^{a}$ Distinción entre el poder espiritual y el temporal, simbolizados en el texto de Jesucristo: "dad al César lo que es del César y a Dios lo que es de Dios" $21 ; 2^{a}$ deber de colaboración entre ambos poderes y $3^{a}$ superioridad del poder espiritual sobre el temporal22. A la autoridad de la Iglesia le compete juzgar de los actos temporales relacionados con lo espiritual. Estas ideas habían sido establecidas por San Agustín en su Ciudad de Dios y en algunas de sus Cartas para lograr una república cristiana. Esta doctrina ha sido denominada Agustinismo político, que defendió el Estado confesional, tal como se había establecido anteriormente en la constitución Cunctos populos del emperador Teodosio en el 380. Estuvo vigente en España, con algunos breves paréntesis, desde el III Concilio de Toledo (año 589) hasta $1978^{23}$.

A las tres ideas vertebradoras de la sociedad medieval se unió otro principio muy importante: predominio de lo comunitario sobre lo individual, uno de los mayores aportes de la Filosofía cristiana a la cultura de Occidente, que había sido aglutinada al mismo tiempo por san Agustín y otros santos padres, haciendo una conjunción o simbiosis de tres grandes aportes o culturas: $1^{\circ}$ Religión de Israel, que anunciaba al verdadero Mesías, Cristo; $2^{\circ}$ la Filosofía Griega y $3^{\circ}$ el Derecho Romano, que va a marcar a perpetuidad las coordenadas del pensamiento jurídico. A estas ideas se unen otras de caballería, resaltando el honor y los valores humanos. Las ideas de fraternidad y de igualdad esencial de los hombres radican en que son hijos de Dios. Se hicieron varias formulaciones de derechos humanos en 1188 en las Cortes de León, 1215 en la Carta Magna inglesa, 1265 en las Cortes de Ejea, Aragón, etc. ${ }^{24}$.

En la Cristiandad medieval, la mujer era igual al hombre como persona. Podía ser abadesa, reina y tener los mismos derechos que un rey. Esto lo defendió uno de los principales formadores y maestros de Isabel la Católica, fray Martín de Córdoba, agustino, que le dedicó su obra Jardín de Nobles Doncellas $^{25}$, donde puso en práctica las ideas de la Cristiandad medieval tal

21. Mt. 22, 21; Mc. 12, 17 y Lc. $20,25$.

22 Gelasio, (Papa 492-496), Carta al emperador Anastasio, "Epistola 8 ad Imperatorem Anastasium" en Patrología Latina, PL, 60, 42.

23. CAMPO, Fernando, "Agustinismo político en España", Augustinus, Presencia de San Agustín en España, 25 (1980) 180-207. Hay una evolución de la polis griega y la civitas romana a la Cristiandad.

24. CAMPO, Fernando, "Los derechos humanos, su evolución histórica, formulación y recepción en la Iglesia católica", Estudio Agustiniano. 35 (2000) 599-600.

25 CórdobA, Martín, Jardín de Nobles Doncellas, edic. por Félix García, pp. 69-74, donde alega como motivo final: "Señora, quise tomar este trabajo de hacer una breve escritura que ha- 
como aparecen en el opúsculo o tratado sobre la Potestad eclesiástica del mismo Martín de Córdoba ${ }^{26}$. Se recoge algo de esto en los Artículos del postulador Dr. D. Vicente Rodríguez Valencia, que afirma en art. 6: "Completa la educación de adolescencia fray Martín de Córdoba, agustino. La Reina Madre le encarga una obra educativa para la princesa. Es el Jardín de nobles doncellas. Dice el educador a la Infanta: Vemos la noble infancia vuestra que en la edad que es (16 años) tiene tal olor de florecientes virtudes; las cuales muestran que cuando el fruto será maduro tendrá perfecto dulzor de graves costumbres.... Regir es obra divinal. Si a todas las vírgenes así conviene que hablemos, tanto más aquélla que debe ser resplandor de castidad y limpieza en todo este reino. La Virgen, árbol de la Vida. Aunque todos los fieles en ella deben haber [un modelo], empero en especial la señora Princesa"27.

Martín de Córdoba opinaba que las mujeres podían gobernar o tener regimiento, igual o mejor que los hombres y que están más dispuestas a vivir las tres virtudes teologales: fe esperanza y caridad. Se apoya en san Agustín para poner de relieve la importancia de la fe y el bautismo ${ }^{28}$ por el que nos hacemos cristianos e incorporamos a la iglesia. Las princesas y reinas "deben ser ejemplo a todos de honrar y servir a Dios y defender a la Iglesia y a las personas de ella"29. Le recuerda textos de san Agustín y le da este consejo: "procure la cristianísima Princesa, cuando tuviere hijos, que sean criados

ble de la generación y condición, composición de las nobles dueñas; en especial de aquellas que son o esperan ser reinas, esperando por este trabajo de sólo Dios galardón, por lo cual los reyes reinan y los siervos son dignos de ser reyes. Allegóse a esto la gran binevolencia [benevolencia] que hobe [tuve] a mi Señor, de gloriosa memoria, el Rey don Alfonso, vuestro hermano, y la gran devoción que él en mí tenía y por su dulce y real clemencia". Como afirma el P. Félix García, que pone grafía moderna para facilitar su lectura "Su prosa fluye lozana y garbosa. La construcción es ya firme y lograda; la sintaxis suelta y airosa. Abunda en giros y expresiones familiares que, como más tarde con fray Luis, adquieren categoría literaria" (ibíd., pp. 61-62). Por éste y otros escritos ha sido incluido en el Diccionario de Autoridades de la Real Academia Española. RuBio, Fernando, "Estudio preliminar. Fray Martín de Córdoba", Biblioteca de Autores Españoles, 171 , pp. X-XXVII.

26. CAMPo DEL POZo, Fernando, "Opúsculo sobre la potestad eclesiástica de Martín de Córdoba", La Ciudad de Dios, 208 (1995) 672-673, donde se expone la distinción de poderes y cómo el poder espiritual de jurisdicción podía ser ejercido por los laicos, como sucedió con el derecho de patronato. El Código de Derecho Canónico de 1983, c. 129 \& 2 sólo admite que "pueden colaborar a tenor del derecho".

27. CóRdoba, Martín, Jardín de Nobles Doncellas, Prohemio, p. 70. RodRíguez VAlEnCIA, Vicente, Artículos del postulador sobre la fama de santidad, vida y virtudes de la sierva de Dios IsabeI, Reina de Castilla, Valladolid 1972, p. 7, donde se cita a la Documentación, v. 4, documento 246 , pp. 51,82 y 83 . La documentación ocupa 42 volúmenes.

28. CóRdobA, Martín, Jardín de Nobles Doncellas, parte $2^{\text {a }}$, cap. 3, p. 158.

29. Ibid., p. 159. 
por amas devotas y católicas que les nombren a Jesús y Santa María y San Miguel" ${ }^{30}$.

b) Características del caballero cristiano, como defensor de la fe y la justicia

Si no se concebía en la baja edad media en Europa, especialmente en la reconquista española, el ser caballero sin ser cristiano, como se ha observado anteriormente y defendió el gran filósofo Manuel García Morente ${ }^{31}$, conviene precisar las características del caballero cristiano, como lo fue Isabel. Ella recorrió a caballo "las vastedades de su reino para presidir los juicios de la santa hermandad", es decir, para hacer justicia ${ }^{32}$.

La primera característica del caballero cristiano es la vivencia de la fe con alegría, que le ilumina. Esa vivencia de la fe le orienta hacia causas nobles, como es comunicarla a los demás y extenderla. Esa fe da seguridad en esta vida y en la otra con ansias de eternidad. Esta fe sólida sirvió de base a las catedrales e iglesias con sus torres que se elevan hacia el cielo como pararrayos protectores de la comunidad cristiana. Es razonada unas veces y otras más honda que la razón y previa a la misma como la del carbonero del que nos habla el célebre obispo abulense Alfonso de Madrigal, conocido con el sobrenombre del Tostado. Esa fe es la que estructura la religiosidad popular. Tenía que ser limpia y pura, por lo que se corrigen como herejía los errores contra la fe.

La segunda es su confianza en Dios con un sentido providencialista y cierta impaciencia de eternidad para cumplir bien con los deberes de su oficio. Como observa Vicente Rodríguez Valencia, "erraba graciosamente Gómez Manrique, al recomendar a la reina [Isabel] en el Regimiento de Príncipes, menos rezos y más gobierno: No con muchas oraciones... No que vistades cilicio/ ni que fagades abstinencial, mas que vuestra excelencial use bien de aquel oficio/ de regir y gobernar/ vuestros reinos justamente" 33 . Se cumple lo que dice el Salmo $1^{\circ}$ "dichoso el hombre que pone su confianza en el Señor"34. El caballero cristiano y español quiere la eternidad buscando la

30. Ibid., p. 163.

31. García Morente, Manuel, La idea de la Hispanidad. I. España como estilo. II. El caballero cristiano, Bueno Aires, 2 edic. Espasa 1959, pp. 116-123.

32. Maeztu, Ramiro de, Defensa de la Hispanidad, 3 ed., Valladolid 1938, p. 258.

33 Rodríguez Valencia, Vicente, Perfil moral de Isabel la Católica, pp. 300-301, donde se cita a Gómez Manrique, destacando la piedad de la reina como imitadora de los santos. La confianza en Dios se compagina como la caridad con la justicia en los santos.

34. Salmo 1,2 . 
salvación, la santidad, etc. No se puede vivir en pecado, sino en gracia. Sus almas arden en llamas de amores hacía Dios y el prójimo. Por eso surgen las confraternidades gremiales y penitenciales. Se vive cada día modelando nuestra arcilla en relación con Dios y con el prójimo.

La tercera es el deseo de ser paladín de la justicia y de causas nobles. Esto lo ha recogido muy bien Cervantes en su inmortal Don Quijote de la Mancha. Hay una filosofía y teología popular en esta obra ${ }^{35}$, donde se entremezclan las ideas nobles con la cruda realidad, lo humano con lo divino. Hay ansias de "desfacer entuertos", de justicia y de paz, incluso de felicidad, que no encontraremos sino en Dios, como dijo San Agustín ${ }^{36}$. El concepto cristiano del ser humano en la baja edad media está unido a las ideas de caballería y caballerosidad con fidelidad a la Iglesia. El cristiano era por el bautismo hijo de Dios y de la Iglesia, algo que la Reina Isabel vivió cada instante y cada momento como perteneciente a la Iglesia, que luego le otorgará el título de "Católica".

Baltasar Castiglione, que llegó a ser nuncio en España, la consideró superior en todo a los reyes y príncipes de su época y se formula esta pregunta: "¿Qué rey o qué príncipe hemos visto en nuestros días o hemos oído decir que haya sido muchos años atrás en la Cristiandad, que merezca ser comparado con la reina $D^{a}$ Isabel de España?... No ha habido en nuestros tiempos [siglos $X V-X V I]$ en el mundo más glorioso ejemplo de verdadera honradez, de grandeza de ánimo, de prudencia, de temor de Dios, de honestidad, de cortesía, de liberalidad y de toda virtud, en fin, que esta gloriosa Reina"37. El mismo B. Castiglione, recoge una serie de coloquios sobre el ideal renacentista del Caballero y la Dama, donde expone lo que se venía diciendo por los que trataron a Isabel la Católica: " Además de esto, afirman todos los que la conocieron haberse hallado en ella una manera divina de gobernar, que casi parecía que solamente su voluntad bastaba por mandamiento, porque cada uno hacía lo que debía sin ningún ruido, y apenas osaba nadie en su propia posada y secretamente hacer cosa de que a ella le pudiera pesar. $Y$ desto nació tenele los pueblos un extremo acatamiento mezclado con amor y con miedo, el cual está todavía en los corazones de todos tan arraigado, que casi muestran creer que ella desde el cielo los mira, y desde allá los alaba o los reprende de sus buenas

35. Rubio Calzada, David, La filosofía del Quijote, 3 edic., Valladolid 1951, pp. 154-193.

36. Agustín, San, Confesiones, lib. 1, cap. 1, n. 1, traducción y edición crítica por Ángel C. Vega, Madrid 1946, p. 25 Cf. MALÓN DE CHAIDE, Pedro, Libro de la conversión de la Magdalena, prólogo de 1588, Barcelona 1881, pp. 18-19, donde pone de relive las características del caballero cristiano y los libros de caballerías.

37 Castiglione [CASTEllón] Baldassare [Baltasar], El Cortesano, trad. por Juan Boscán, Barcelona 1534 edic. de Mario Pozzi, lib. III, n. 35, Madrid 1994, p. 388. B. Castiglione (14781529) fue nuncio en España desde 1524 hasta su muerte en 1529. 
o malas obras, y así con sólo su nombre y con las leyes establecidas por ella, se gobiernan aún aquellos reinos de tal manera, que aunque su vida haya fallecido, su autoridad siempre vive, como rueda movida con gran espíritu largo rato, después ella misma se vuelve como de suyo por buen espacio, aunque nadie la vuelva más"38. Esto le lleva a afirmar a Julián Marías de acuerdo con Castiglione, que "Isabel la Católica tenía un evidente derecho a gobernar. No ya por sus títulos dinásticos sino por la ejemplaridad de su ejercicio. Por eso su muerte, la terminación de su poder, de su capacidad de acción, de imperio, no afecta a su vigencia. Sigue ejerciendo esa potestad que le fue conferida por su conducta. Sigue teniendo un influjo que va más allá de los posibles medios de coacción. Nadie se atreve a discrepar de las normas de quien ya no puede imponerlas. Ese poder irreal al que se refiere Castiglione es una admirable descripción de la autoridad" 39 .

Entre las obras, que tenía Isabel la Católica se encontraban la Ciudad de Dios, De civitate Dei de san Agustín y el tratado del Regimiento de los príncipes en latín, De regimine principum de Egidio Romano, el representante más conspicuo de la Escuela Agustiniana, junto con otros 252 libros, en su mayoría religiosos, históricos y políticos, que resaltaban los valores del caballero cristiano, como El Cartuxano, el Martirologio, La Leyenda aurea, De imitatione Christi, que ella leía en latín, en cuyo idioma rezaba las horas menores del Oficio divino, y no pocas veces las Horas de Nuestra Señora u oficio parvo, etc. Siempre tuvo mucha devoción a la Santísima Virgen, bajo distintas advocaciones, cuyas fiestas celebraba como las de Jesucristo, los apóstoles y los santos según se lo recomendó Martín de Córdoba ${ }^{40}$.

\section{c) Legimitad de Isabel al trono de Castilla y León según la Cristiandad medieval}

Se margina aquí lo referente al pacto de los Toros de Guisando el 18 de septiembre de 1468, con la postura de la nobleza castellana, su matrimonio con Fernando de Aragón en 1469, las legaciones de D. Antonio J. de Veneris o Veniero (1467-1468) y del cardenal Rodrigo de Borja (1472-1473) y la pro-

38. Ibíd., p. 389.

39. MARÍAS, Julián, "Una divina manera de gobernar", en ABC del 1 de marzo de 2001 y en Isabel, n. 25, septiembre/octubre del 2001, pp. 11-13.

40. Sillo CoRTÉs, César, Isabel la Católica fundadora de España. Su vida, su tiempo, su reinado (1451-1504), Valladolid 1939, pp. 526-543. En su biblioteca estuvo el Jardín de Nobles Doncellas, manuscrito y en la edición hecha en Valladolid en 1500. Se terminó de imprimir el 11 de noviembre de ese año. 
clamación de Isabel como reina de de Castilla y de León en 1474, porque está ampliamente tratado y bien documentado. Sólo incidentalmente se hará referencia a su proclamación como reina de Castilla ${ }^{41}$. Se intenta resaltar algo que no es bien conocido, como la intervención de Martín de Córdoba. Este religioso agustino era buen conocedor de la potestad de los papas y de los reyes y fue uno de los que más influyó en la princesa Isabel, a la que siguió aconsejando como reina hasta 1476 . Siendo princesa la consideró legítima heredera al trono de Castilla, como se ha observado anteriormente. Conviene resaltar que Martín de Córdoba, según testimonio del P. Jerónimo Román "era perseguidor acérrimo de los judíos en España y defensor de la fe contra ellos" 42 .

El libro Jardín de Nobles Doncellas está dividido en tres partes: en la $1^{\mathrm{a}}$ se expone la formación de la primera mujer y su generación posterior dentro del plan divino. En la $2^{a}$ se trata de las condiciones favorables de la mujer y de las cualidades que deben tener las doncellas nobles, especialmente las reinas para regir los destinos de los pueblos. En la $3^{a}$ parte se comienza haciendo una recapitulación de lo dicho en las dos primeras partes, resaltando las mujeres que sobresalieron por sus virtudes y le pueden servir de modelo para llegar a ser la mujer fuerte, casta, honesta y sabia de la que se habla en los Proverbios ${ }^{43}$ y en los dichos de los doctores y santos padres. Concluye poniendo el ejemplo de algunos vírgenes y mártires, incluso mujeres nobles paganas, resaltando como modelo ideal a la Santísima Virgen y a Jesús crucificado, en cuyo espejo se han de mirar las doncellas, a las que les dará singular corona. Llega a considerarla futura reina y el capítulo sexto de la parte segunda se titula: "que deben honrar y amar a Dios sobre todas las cosas, y más las reinas que todas las otras mujeres"44. Martín de Córdoba buen conocedor de lo que pasaba en la corte de Enrique IV, defendió el derecho de la princesa Isabel al trono de Castilla y la consideró, como predestinada por Dios para reina de España: "Pues, Dios, que en el vientre de la madre dio y predestinó a ésta para reina de tan noble reino como España, más obligada es a lo amar que otra ninguna"45.

41. VAL, Isabel del, Isabel la Católica princesa (1468-1474), pp. 61-199 y 292-351.

42. Román, Román, Chrónica de la Orden de los ermitaños del glorioso Padre Sancto Augustín, diuidida en doze Centurias compuesta por, etc. Centuria 11, 4, Salamanca 1568, f. 94v; lib. 4 en la edición de Madrid 1865, p. 8 Cf. GarCía, Félix, "Prólogo" Jardín de Nobles dDoncellas, p. 8.

43. Proverbios, $31,10$.

44. CóRDOBA, Martín de, Jardín de Nobles Doncellas, parte 2, cap. 6, ed. de Félix García, p. 181.

45 Ibíd., pp. 185-186. Vuelve a considerarla otra vez reina de España en la p. 186. 
Isabel llegó a gobernar no sólo por derecho, con legítimo título dinástico, sino también por voluntad popular que la admiraba y quería por su belleza espiritual y física, sirviendo de modelo de Dama, mujer perfecta en su vida privada y pública. Tuvo buenos consejeros y se atuvo a las disposiciones de la Iglesia, a la hora de tomar decisiones importantes, como fue la de su matrimonio con Fernando. Así, a primeros de enero de 1469 consulta al colector pontificio o legado y luego nuncio Veneris o de Veniero la solución canónica de su matrimonio obteniendo en secreto la dispensa pertinente, dando "testimonio contundente de fe, fortaleza de espíritu, prudencia y paciencia superior a cuanto de semejante haya podido conocerse en la historia de los príncipes" 46 .

El.13 de diciembre de 1474, después de ser proclamada reina de Castilla y de León en Segovia, como observa D. Vicente Rodríguez Valencia, conviene resaltar de entre todas las ceremonias de su toma de posesión, su entrada en la iglesia de San Miguel, donde después de hacer oración, tomó en sus manos el pendón real y "ofreció el dicho su pendón a Dios en las manos de un preste que en el dicho altar estaba puesto para recibir esta ofrenda"47. Se proponía servir a Dios y la Iglesia, que se aferraba en el siglo XV al ideal medieval de la política eclesial de la Cristiandad con la doctrina de la potestad indirecta sobre lo temporal.

\section{Su actuación como fiel hija de la Iglesia y sus relaciones con la Santa Sede}

Su actuación como fiel hija de la Iglesia se constata por las consultas que hacía a su confesor fray Hernando de Talavera y a otras personas entendidas, como fray Martín de Córdoba, el cardenal D. Pedro González de Mendoza, cuando era arzobispo de Sevilla, y miembros del Consejo Real. En su horario semanal, fijado por su confesor, estaba el de oír los lunes al prior del monasterio de Prado, que era Hernando de Talavera, los martes oír las consultas del Consejo, etc. 48

\section{a) Por qué estableció la Inquisición en Castilla y expulsó a los judíos}

La actuación de Isabel como fiel hija de la Iglesia consta por sus relaciones con la Santa Sede a través de los legados pontificios y del nuncio perma-

46. Rodríguez Valencia, Vicente, Artículos del postulador sobre la fama de santidad, etc., Valladolid 1972, art. 15, p. 13.

47. Ibíd., art. 16, p. 14, donde se menciona la D [Documentación] V [volumen], documento 332 , p. 264.

48. Ibíd., art. 21, p. 17. 
nente, que se estableció en su reinado, siendo el primero D. Francisco de Prat (1492-1503). Anteriormente eran legados y colectores, que intervenían también en la solución de conflictos. Aunque Fernando e Isabel, como reyes legítimos, tuvieron conciencia de su naciente soberanía mayor en España que en el resto de Europa, deseaban garantizar el bien de la Iglesia católica y prestarle su apoyo con el brazo secular. Se hizo esto con el establecimiento de la Inquisición en Castilla para desenmascarar a los judaizantes que presentaban serios problemas políticos y religiosos con el delito de apostasía, de herejía, proselitismo, subversión y otros.

Funcionaba la Inquisición en 1231 con el papa Gregorio IX y san Raimundo de Peñafort, como un tribunal eclesiástico. Se reorganizó con Clemente V al establecer el proceso inquisitivo en 1306, con su decretal Saepe contingit ${ }^{49}$, que ha servido de base para lo que se llama proceso sumario. Funcionaba la Inquisición en los Estados pontificios y en varias naciones europeas como Francia, incluso de un modo incipiente en Aragón, con tribunales pontificios a cargo de los dominicos. Se quería establecer la Inquisición en Castilla con una organización centralizada y seria. Les fue concedido este privilegio por Sixto IV el 1 de noviembre de 1478. Se autorizaba a Isabel y Fernando el privilegio de nombrar dos o tres inquisidores, obispos $u$ otros eclesiásticos competentes, de 40 años, maestros o bacalaureados en Teología o Doctores o licenciados en Derecho canónico, con buena conducta. Debían de actuar según el Derecho, uso y costumbre de los jueces eclesiásticos ${ }^{50}$.

La reina Isabel no quiso hacer uso inmediato de la autorización, sino que esperó el resultado de las ordenanzas dadas contra los apóstatas. El 17 de septiembre de 1480 éstableció el Santo Oficio con una real cédula nombrando inquisidores para el reino de Castilla a los dominicos fray Miguel Morillo, que era provincial, y fray Juan de San Martín, prior del convento de Sevilla. El papa Sixto IV aprobó esta elección y amplió la facultad a siete jueces con estrecha dependencia de los Reyes y del inquisidor general Tomás de Torquemada. El 2 de enero de 1481 se publicó un edicto en el que se invita-

49. Clemente V, "Saepe contingit quod causas committimus, etc., del 19 de noviembre de 1306. Clementinas, 5, 11, 2, Friedberg, Aemilius, Corpus Iuris Canonici, II, col. 1100. La Inquisición y el proceso sumario se remontan a los siglos XII y XIII con orígenes romanos y se institucionalizan formalmente con Clemente V, el XIII de las calendas de diciembre, 11 de su pontificado. Cf. Lefevre, Charles, "Les origenes romaines de la Procedure Sommaire aus XII et XIII".., Ephemerides Iuris Canonici, 12 (1956) 149-197. Los Reyes Católicos siguieron las directrices de la Iglesia Católica, como hijos de ella.

50. Bulario Pontificio de la Inquisición Española en su periodo constitucional (1478-1525), ed. por Bernardino Llorca, Roma 1949, 3, p. 53. Luego se amplió la jurisdicción siendo gran inquisidor Tomás de Torquemada en 1483. 
ba a los apóstatas a que se reconciliaran con la Iglesia y volviesen a sus domicilios. A los judíos se les ofrecía tolerancia si se abstenían de profanar los misterios cristianos. Bastantes judaizantes se reconciliaron, algunos falsamente, mientras que otros siguieron cometiendo atropellos, profanaciones y crímenes como el Niño de La Guardia (1489) en Toledo, etc. ${ }^{51}$. Este caso y otros, como el de la Sagrada Hostia, que se conserva incorrupta según fue consagrada en 1489 en el Monasterio de Santo Tomás de Ávila, fueron motivos serios para la expulsión de los judíos. Se trataba del ser o no ser de la España católica y de su unidad. La Inquisición dependía estrechamente de lsabel y Fernando que decidieron la expulsión de los judíos por pragmática del 31 de marzo de 1492. Esto se hizo de acuerdo con las ideas de la Cristiandad y beneplácito de Sixto IV. Según consta en la Positio: "La medida estaba imperada por exigencias del Estado, con mayores razones que las que hoy existen en los delitos contra la seguridad del Estado y que se substancian en los gobiernos modernos" 52 . Se hizo de acuerdo con la doctrina y praxis de la Iglesia.

Conviene observar que hay que ver la expulsión de los judíos y la actuación de la Inquisición en su época. Sólo los que desconocen la verdadera historia o no tiene buena intención, pueden hablar mal de ella. Tenemos el caso de san Pedro de Arbués, buen inquisidor, asesinado por los judíos el 14 de septiembre de 1485 en la catedral de Zaragoza ${ }^{53}$. Consta en su proceso de canonización, según el historiador del Derecho, Juan Beneito, que san Pedro de Arbués se le apareció nimbado de gloria poco después de su muerte a Mosén Blasco Gálvez, con el encargo de que Fernando e Isabel continuasen la conquista de Granada y que mantuviesen el Santo Oficio, pues estas dos empresas les darían la vida eterna ${ }^{54}$.

51. Minguijón, Salvador, Historia del Derecho Español, 2 edic. Barcelona 1933, pp. 386-391. Sobre el Santo Niño de La Guardia hay mucha bibliografía. Cf. CANTERA Burgos, Francisco, "El Santo Niño de La Guardia", Año Cristiano, III, Madrid 1965, pp. 735-741; BelmonTe DíAz, José, Judios e Inquisición en Ávila, Ávila 2003, 203 pp.

52. Positio super scriptis, etc. Roma 1973, pp. 4-5 y 7, donde se menciona la Relación, p. 23. El ejemplar que se usa está fotocopiado del que perteneció a D. Vicente Rodríguez Valencia con fecha 16 de julio de 1973. La parte histórica ha sido aprobada en 1991.

53. LlORCA, Bernardino, La Inquisición en España, Barcelona 1936, pp 124-149. Cf. PINTA LLORENTE, Miguel de la, La Inquisición Española y los problemas de la cultura y la intolerancia, Madrid 1958.

54 Beneyto, Juan, "San Juan de Arbués", Año Cristiano, $2^{\mathrm{a}}$ ed. por Lamberto de Echeverría y Bernardino Llorca, III, Madrid 1965, p. 672. 


\section{b) Su fidelidad a la Iglesia en el Pacto concordatario de 1482 y el Derecho de Patronato}

La fidelidad de Isabel de Castilla con la Iglesia, especialmente con la Santa Sede, se constata a través de las actuaciones de los legados pontificios. Desde el siglo XIII existían en España los llamados colectores, que estaban encargados de cobrar las sumas debidas por distintos conceptos a la Cámara Apostólica. A mediados del siglo XV había un colector en Aragón y dos en Castilla dada su extensión. Algunos colectores tenían otros encargos especiales por ser legados pontificios y nuncios. Su misión principal era la recaudadora.

Durante la Legación pontificia de D. Nicolás Franco, obispo de Treviso y colector general de Castilla y León (1475-1478) se presentaron problemas y tensiones sobre bienes consistoriales y el nombramiento de obispos. En Castilla existía la costumbre de que el cabildo catedralicio informase al rey de la muerte del obispo para ver cuáles eran sus deseos, porque el obispo electo tenía que solicitar de él las temporalidades. De hecho, en España, desde el cisma de Occidente, se nombraba los obispos según las Decretales y las Partidas de Alfonso el Sabio, por el cabildo catedral, con cierta intervención del rey. Juan II de Castilla obtuvo en 1421 de Martín V, después del Concordato de Constanza del 13 de mayo de 1418, el derecho a intervenir como patrono de las iglesias catedrales fundadas durante la Reconquista por sus antecesores y Enrique IV en 1456 y 1459 obtuvo garantías de Calixto II y Pío II que tendrían en cuenta los candidatos propuestos por los reyes y sus deseos en las provisiones episcopales. Hubo tensiones en el nombramiento del obispo de Zaragoza (1475-1478), Tarazona (1478-1482) y Cuenca (14781482), el más conflictivo al morir en Roma el cardenal Antonio de Veniero (Veneris) obispo de Cuenca el día 3 de agosto de 1479. "El mismo que, durante su legación, presidiera la concordia de Guisando, según afirma Luis Suárez: "El papa usando del criterio de cubrir en Curia los cargos vacantes en Curia, nombró obispo de Cuenca el día 13, a su sobrino el cardenal Rafael Riario, aunque era casi un muchacho. La decisión había sido tan rápida que a un mismo tiempo se supo la vacante y el nombramiento. Los reyes se negaron a aceptarlo. El 30 de septiembre Isabel ordenaba al sobrino del difunto, Gabriel Condulmer, que continuara desempeñando como hasta entonces la administración" 55 . El problema se complicó más después del Concilio nacional de

55. SuÁrez Fernández, Luis, Política internacional de Isabel la Católica, Valladolid 1965, pp. 247-248. Estaba preso en Roma el agente de los reyes, Francisco de Santillana, por orden del papa Sixto IV. 
Sevilla (1478) en el que se trató también del derecho de súplica en la presentación de obispos, al ordenar Fernando, el 6 de noviembre de 1479, que todos cuantos fuesen portadores de bulas concediendo beneficios a extranjeros, sin su beneplácito, fuesen llevados presos a la Corte, dándose también un caso indirecto de retención de bulas. Esta política no era de Isabel sino de Fernando, que luego, el 12 de junio de 1482, nueve días después de firmar el acuerdo del que vamos a tratar, prohibió a sus súbditos de la Corona de Aragón solicitar u obtener cargos eclesiásticos sin su autorización ${ }^{56}$.

Se daban casos de cierta autonomía del papa y del rey en la provisión de beneficios eclesiásticos, como sucedió con el establecimiento de la abadía y colegiata en la iglesia parroquial de San Antolín en Medina del Campo, por bula del 20 [11] de junio de 1480, con cierto derecho de patronato. El abad tenía insignias y jurisdicción cuasi-episcopal. Se nombraba el abad entre los capitulares del cabildo. De ahí viene el mote del escudo de Medina del Campo: "ni el rey oficio, ni el papa beneficio". Intervino D. Juan Ruiz de Medina, que fue segundo abad y se encontraba en Roma ese año, con el Conde de Tendilla, para solucionar los problemas que había entre Inocencio VIII y Fernando, que era rey de Nápoles. El abad de Medina fue el destinatario de la Bula Inter caetera ${ }^{57}$.

Siendo aún colector Doménico Centurione [Centurión] y a punto de establecerse la primera nunciatura permanente, se hace una concordia, primero entre el deán y cabildo de Cuenca con los reyes, y luego entre el papa Sixto IV e Isabel de Castilla y Fernando de Aragón con el privilegio de provisión de sedes episcopales con motivo del conflicto surgido acerca de la diócesis de Cuenca y otras vacantes. Se encauzó la solución a este problema, sirviendo de antecedente jurídico-canónico para otros casos, por lo que se puede considerar como un concordato. Aparecen incluso las palabras "Pacta composita et Concordata" del 3 de junio de 1482, por lo que fue considerado por Laureano Pérez Mier, como un concordato precedente inmediado del francés del 18 de agosto de 1516 entre Francisco I y León X. Ha sido negado su carácter concordatario por Clemens Bauer y otros, como Tarsicio de Azcona ${ }^{58}$. Luis

56. Archivo General de Simancas, Registro del Sello, 1479,-XI- f. 12. Cf. SUÁREZ, Luis, Politica internacional de Isabel la Católica, p. 248 y 258.

57. METZLer, Josef, America pontificia primi saeculi evangelizationis, 1493-1592, Vaticano 1991, pp. 72-83; RODRÍGUEZ Y FERNÁNDEZ, Ildefonso, Historia de la muy noble, muy leal y coronada villa de Medina del Campo, Madrid 1903-1904, pp. 98, 104-107 y 520-521.

58. PÉrez Mier, Laureano, Iglesia y Estado nuevo, Madrid 1940, p. 290; BAUERs, Clemens, "Studiens zur spanischen Konkordatgeschischte des späten Mittelalters. Gresammelte Aufsätze zur Kulturgeschiscte Spaniens", Spanische Forschungen der Görres Gesselschaft, 11 (1955) 
Suárez lo considera como un concordato, en el que Fernando e Isabel se sentían satisfechos "porque en ningún momento habían mostrado al papa falta de respeto o amago de violencia, el concordato daba a entender que existía un derecho de presentación por parte de los reyes y que, en adelante, ningún obispo sería nombrado sin que ellos interviniesen"59. En ese año de 1482 se intensifican las relaciones de Fernando e Isabel con la Santa Sede y se establecen los primeros embajadores permanentes ante Sixto IV60.

La solución al problema de los beneficios consistoriales y la elección de obispos con el derecho de presentación se va a solucionar con la bula Ortodoxie fidei dada por Inocencio VIII, el 13 diciembre de 1486, concediendo el Derecho de Patronato ${ }^{61}$, ampliado en la bula Inter coetera del 3 de mayo de 1493 y ratificado por Julio II en la bula Universalis Ecclesiae del 28 de julio de 1508 publicada por Pedro de Leturia, según el cual, el Patronato fue beneficioso para España y para la Iglesia, especialmente en tiempo de los Reyes Católicos ${ }^{62}$. Esto ha sido ampliamente expuesto por Antonio María Rouco Varela, que ha emitido un juicio muy favorable sobre la actuación de Isabel, reconociendo que hubo tensiones, porque la Iglesia quería salvaguardar su autonomía y libertad para el nombramiento de obispos ${ }^{63}$.

El Patronato dio origen a lo que Alonso de Veracruz denominó Vicariato Regio, porque contiene una delegación pontificia, de la que hizo buen uso Isabel la Católica para la Indias. Hicieron uso de él sus sucesores, especialmente Felipe II ${ }^{64}$.

c) Isabel manifiesta su amor reverencial al papa Alejandro VI con una corrección filial

Isabel no vio bien el nombramiento de Rodrigo de Borja primero para arzobispo de Sevilla y luego para papa. Ella estaba agradecida por la colabo-

\footnotetext{
43-93; Azcona, Tarsicio, La elección y reforma del episcopado español en tiempo de los Reyes Católicos, Madrid 1960, pp. 117-119.

59. SuÁrez Fernández, Luis, Política internacional de Isabel la Católica, p. 258. Fue nombrado obispo de Cuenca fray Alonso de Burgos.

60. Pou y Martí, J. M., "Los archivos de la Embajada de España cerca de la Santa Sede", Studi e Testis, 165 (1952) 297-298.

61. Gutiérrez, Constantino, "La Política Religiosa de los Reyes católicos en España hasta la Conquista de Granada", Miscelanea Comillas, 18 (1952) 64-267.

62 Leturia, Pedro de, "La Bula del Patronato de las Indias Españolas, que falta en el Archivo Vaticano. Un intento de reproducción", Analecta Gregoriana, 101 (1959) 233-256.

63. Rouco VArela, Antonio María, Estado e Iglesia, pp. 233-238 y 329.

64. CAMPO DEL POZO, Fernando, "Patronato y Vicariato Regio en Alonso de Veracruz y Gaspar de Villarroel", Anuario Jurídico Escurialense, 25 (Homenaje a Fr. José López Ortiz), El Escorial I (1970) 485-512.
} 
ración, que había prestado siendo cardenal y Vice-Canciller, obispo de Valencia y con residencia en Roma. Actuó como colector y legado en 14721473, con amplios poderes para distintos asuntos que le comisionó Sixto IV. Entre las cinco legaciones que le confiaba el papa como legado en Aragón y Castilla una de ellas era la pacificación y el derecho de Isabel al trono de Castilla y de León, junto con las cuestiones del cobro de la décima de la Cruzada. Los distintos asuntos están especificados en los documentos existentes en el Archivo Vaticano65.

Le agradecía también sus actuaciones ante Inocencio VIII; pero protestó ante el mismo papa cuando le nombró arzobispo de Sevilla, haciendo revocar el nombramiento, porque dependía de ella. Como buena hija de la Iglesia aceptó el nombramiento hecho por el papa y se calló. No pudo hacerlo cuando oyó lo que se decía sobre la fastuosa boda de Lucrecia en Roma. Se sintió obligada, como hija y miembro de Iglesia, a manifestar al papa su corrección con amor y respeto a través del nuncio D. Francisco de Prats. Se trata de un hecho incidental; pero que aclara mucho cómo actuaba Isabel sintiéndose hija de la Iglesia, siendo reina, por lo que conviene incluirlo como un excursus sobre un Informe reservado escrito en valenciano ${ }^{66}$.

Esto es algo interesante e íntimo, que sucedió en Medina del Campo, donde se encontraba la Corte en 1493 y también el nuncio. Lo ha dado a conocer Vicente Rodríguez traduciendo parte del valenciano al castellano. La reina despidió de su estancia a los ayudantes y secretarios, quedándose a solas con el nuncio, algo que no solía hacer. Atrancó la puerta por dentro para que no fuesen interrumpidos y le dijo al nuncio: "que hacía días que quería hablarle y que lo había diferido; porque pensaba enviar una embajada especial a $\mathrm{Su}$ Santidad para darle las gracias por todos los asuntos que le había suplicado. Pero que esta embajada [a través de Diego López de Haro a Alejandro VI] se difería y había pensado hablarle para que transmitiera a Su Santidad sus palabras. [Así quedaba entre los tres]. Que tenía mucha voluntad y amor a vuestra Beatitud...y que se veía constreñida a hablar y tratar algunas cosas que de vuestra Beatitud oía, de las cuales, porque quiere bien a vuestra Santidad, recibía enojo y displicencia, mayormente porque eran tales que engendraban escándalo y podrían traer consigo algún inconveniente; concretamente, las fiestas de doña Lucrecia, y la intervención de los cardenales, es decir, del cardenal de Valencia [hijo de Rodrigo de Borja, el papa] y del cardenal Farnesio y del cardenal de Luna; y que yo, de parte de su Majestad, escribiese a vuestra

65. FernÁNDEZ Alonso, Justo, Legaciones y Nunciaturas en España, I, doc. 58-82, pp. 84118.

66. Archivo Secreto Vaticano, Archivum Arcis, arm. I-XVIII, vol. 52023, ff. 61v-64. 
Beatitud, quisiera mirar mejor estas cosas, etc.". El nuncio le observó a Isabel "que no tenía razón para estar tan enojada de las cosas de vuestra Santidad, y que bien se veía que su Majestad, no había querido comprender ¿comparar? la vida de los otros Pontífices predecesores a vuestra Beatitud. Que él había corregido algunas cosas de los papas predecesores Sixto IV e Inocencio VIII". El mismo Alejandro VI aceptó bien la amable corrección, porque la admiraba, conocía su buena voluntad y la quería, lo mismo que a su pariente y "compadre", Fernando, que quedó al margen de la conversación y del informe. En ese mismo año de 1493 les concede nuevas facultades, y el 19 de diciembre de 1496 les otorga el título de "Reyes Católicos"67.

Alejandro VI, siendo cardenal y colector había defendido los intereses de España ante Inocencio VIII y lo siguió haciendo siendo papa. Le había apoyado Fernando de Aragón decididamente para conseguir la tiara. Como papa colaboró para la reforma de la Iglesia en España, especialmente de las Órdenes religiosas con sus bulas desde 1490 hasta 1500. La reina Isabel influyó decididamente en la empresa reformadora, donde se constata su religiosidad y "sus esfuerzas espirituales y eclesiales"68. Con el descubrimiento de América en 1492 y las bulas Inter caetera, dadas por Alejandro VI en 1493, va a surgir además del Patronato y el Vicariato Regio, lo que se llama Hispanidad, como algo perenne, y realidad en la que influyó decididamente Isabel la Católica.

\section{El ideario indigenista de Isabel, como hija de la Iglesia, dio origen a la Hispanidad}

La palabra Hispanidad fue acuñada o animada por Mons. Zacarías de Vizcarra y Arana (1880-1963), que distinguió entre hispanidad con minúscula e Hispanidad con mayúscula, como un conjunto de cualidades y valores, que distinguen a los pueblos de estirpe y cultura hispánica del resto de naciones del mundo. Mons. Vizcarra llegó a ser Consiliario Nacional de la Acción Católica y fue consagrado obispo titular de Eressus el 22 de junio de 1947. El concepto y contenido de la Hispanidad ha sido expuesto magistralmente por

67. Rodríguez Valencia, Vicente, Perfil moral de Isabel la Católica, Valladolid 1974, pp. 224-227. Esto aparece en la Documentación, XV, documento 1809, pp. 45-48.

68. Ibíd., pp. 203-204 y 227. Cf. GARCía ORO, José, La reforma de los religiosos en tiempo de los Reyes Católicos, Valladolid 1969, Introducción, pp. 133-134, donde se resalta el papel de Isabel. Se recoge en la Documentación, $\mathrm{X}$, reconociendo también la colaboración de Alejandro VI, del cardenal Cisneros, etc. 
Ramiro de Maeztu (1871-1936). Ambos nacieron en Vitoria. Maeztu es uno de los representantes más conspicuos de la llamada generación del 98 . Fue colaborador de la Acción Católica, especialmente a partir de 1928, y en 1934 publicó su Defensa de la Hispanidad, que fue uno de los motivos de su fusilamiento en Madrid a comienzos de la guerra civil en 1936. Era Académico de la Lengua desde 1934. En Defensa de la Hispanidad, menciona seis veces a Isabel citando y recordando su Testamento, donde se afirma que "el fin principal e intención suya y la del Rey su marido, de pacificar y poblar las indias, fue convertir a la Santa Fe Católica a los naturales", algo que encargaba a sus príncipes herederos y que se les diera el mejor trato ${ }^{69}$. Se debía de cumplir el encargo de evangelizar a los aborígenes del Nuevo Mundo, que les había confiado la Iglesia, de la que se consideraban fieles hijos. Esto lo ha expuesto bastante bien D. Gregorio Marañón Moya, haciendo ver que para el iusfilósofo D. José Corts Grau, la Hispanidad y el "ideal hispano es materia de presente; pero que pertenece al pasado y al presente, y ha de ser ante todo futuro"70.

\section{a) Indigenismo de Isabel la Católica con un Estado moderno y un Mundo Nuevo}

Isabel la Católica, como fiel hija de la Iglesia y de acuerdo con la misión encomendada, defendió los derechos de los aborígenes del Nuevo Mundo, como seres libres desde 1493 y los siguió defendiendo hasta su muerte, exigiendo la abolición del comercio de esclavos y la devolución al lugar de origen. Fue consecuente con la doctrina canónica y teológica que le había enseñado fray Martín de Córdoba, sacando conclusiones, para que luego Francisco de Vitoria y otros juristas hispanos desarrollasen el derecho de Gentes $^{71}$.

La colonización española es la más humanitaria, porque se justificó de acuerdo con las ideas de la Cristiandad medieval y según la doctrina del Evangelio. Se procuró evangelizar a los aborígenes de América, y que se les instruyese como a los nacidos en España. Esto aparece en una ordenanza dada en Zaragoza el 29 de marzo del 1503 al comendador Nicolás de Ovando:

69. MAEzTU, Ramiro de, Defensa de la Hispanidad, pp. 46 y 117.

70. Marañón MoYa, Gregorio, "Hispanidad" en Diccionario GER, Gran Enciclopedia Rialp, XI, Madrid 1972, pp. 842-844. Dio una conferencia sobre la Hispanidad en Maracaibo el año de 1957.

71. Rodríguez Valencia, Vicente, Artículos del Postulador, pp. 47-49, donde se mencionan los documentos correspondientes. 
"En las dichas poblaciones e junto a las iglesias, faga hacer una casa, en que todos los niños... se junten cada día dos veces, para que alli el dicho capellán los maestre a leer e a escribir"72. Órdenes semejantes siguen repitiéndose en 1509, 1511 y después. Se despachaban para todo el Nuevo Mundo, que empieza a ser evangelizado o misionado. "Esto que hoy nos parece una disposición sin novedad -como afirmó el P. Pedro Barnola S. J. en 1962-, era un gesto adelantadísimo entonces" 73 .

Ya en real cédula de 20 de junio de 1500 se había lamentado la Reina de los abusos que se estaban cometiendo en la Española, ordenando en las instrucciones dadas al gobernador Ovando de 16 de septiembre de 1501, que pusiera en libertad a los indios repartidos y de acuerdo con los caciques, señalase el tributo que aquellos, como vasallos libres, debían satisfacer, debiendo "compelerlos... a trabajar en las cosas de nuestros servicios, pagando a cada uno el salario que justamente vos parecieres e devieren de aver, según la calidad de la tierra"74.

Al concepto de Cristiandad, con un Estado al servicio de la Iglesia, se une un nuevo concepto de Estado moderno, que expuso Maquiavelo, considerando a Fernando el Católico como modelo y uno de sus promotores. Se dan exigencias del Estado a la Iglesia, como ha observado Antonio $\mathrm{M}^{\mathrm{a}}$ Rouco Varela: "Se inició un completo proceso de cambio en la disposición del poder del Estado, que a lo largo del siglo se madurará en un verdadero aparato estatal, que sin duda estaba en la línea del moderno estado administrativo. El rey, en torno al cual se llevó a cabo la vuelta en sí del Estado moderno, la conciencia de su soberanía, fue el punto clave de esta evolución. Alrededor de él, que unía en sí, como fundamento del Estado, la legislación suprema y el poder judicial y administrativo, se erigió un edificio compacto de autoridades reales centrales $y$ provinciales"75. Se va a aplicar un Derecho Medieval a un Mundo Nuevo con el derecho de Patronato y un elemento estatal, moderno y regalista. Esto

72. AGI, Indiferente General, 418, lib. 1, f. 904rv. Cf. ROMEU DE ARMAS, Antonio, La politica indigenista de Isabel la Católica, Valladolid 1969, pp. 390-395.

73. CAMPO DEL Pozo, Fernando, "Aportes agustinianos a la cultura de América y Venezuela", Pensamiento Agustiniano XIII. Jornadas Internacionales de Agustinología, Universidad Católica Andrés de Bello, Caracas 1998, pp. 134-135, donde se cita a Pedro Barnola y se hace ver que había en España 34 universidades y unas 4.000 escuelas de gramática con un sistema educativo que se trasplantó a las Indias Occidentales y Orientales en el siglo XVI.

74. Colección de documentos inéditos relativos al descubrimiento, conquista y organización de las antiguas posesiones españolas de América y Oceanía, Madrid 1864-1884, tomo VI, p. 177.

75. Rouco VARela, Antonio María, Estado e Iglesia en la España del siglo XVI, pp. 117118. Trata del Patronato real en las pp. 233-290. Omite lo referente al Vicariato Regio desarrollado por fray Alonso de Veracaruz. Cf. CAMPO DEL Pozo, Fernando, "Patronato y vicariato regio en Alonso de Veracruz y Gaspar de Villarroel", pp. 485-512. 
hay que tenerlo en cuenta para comprender la Hispanidad, de la que fue vertebradora Isabel la Católica con su Testamento y Codicilo, donde aparece también su indigenismo con algunos aspectos valiosos, debidos a su esposo D. Fernando, promotor del Estado moderno.

b) EI Testamento y Codicilo de Isabel con su profesión de fe como fiel cristiana

Como era costumbre, comienza su Testamento invocando a la Santísima Trinidad, a la Santísima Virgen, arcángeles y santos de su devoción. Expone la causa o motivo, que es su enfermedad y hace la profesión de fe como fiel hija de la Iglesia. Tanto el Testamento como el Codicilo y su muerte, cuentan con muy buenos estudios; pero no se comprenden bien si no se tienen en cuenta las ideas vertebradoras de la Cristiandad medieval en la que se formó Isabel, que consideró a sus súbditos de África y de las Indias con los mismos derechos que los de Castilla. El 12 de octubre de 1504, duodécimo aniversario del descubrimiento de América, hizo su Testamento con pleno conocimiento'y demostración de gran talento. Lo otorgó ante el notario y escribano de la corte D. Gaspar de Gricio, y en presencia de los testigos, D. Juan Rodríguez de Fonseca, obispo de Córdoba; D. Fadrique de Toledo, obispo de Calahorra; D. Valeriano Ordóñez y Villaquirán, obispo de Ciudad Rodrigo, etc. ${ }^{76} \mathrm{El} \mathrm{Codicilo}{ }^{77}$, que completa el Testamento fue otorgado el 23 de noviembre, tres días antes de morir, dando la impresión de que se encontraba bien, aunque ella preveía un final cercano, mientras seguía preocupándose de sus reinos, de sus vasallos y de su familia. Al enterarse de que se estaban haciendo rogativas y procesiones pidiendo su salud, dijo a los que la acompañaban que "no rogasen por su vida sino por la salvación de su alma"78.

Encargó que se le hiciesen exequias modestas, deseando que se invirtiese en limosnas a los pobres y en cera para el Santísimo lo que se iba a gastar

76. Testamento de Isabel la católica. El texto original que se encuentra en Archivo de Simancas, Patronato Real, 30-2. Hay varias ediciones, como la hecha por D. Tomás Romojarro Sánchez, Valladolid 1944 y la de la Dirección General de Archivos y Bibliotecas, Testamento y Codicilo de la Reina Isabel la Católica, Madrid 1969, pp. 25-37. Hay una edición facsímil del Testamento y Codicilo, hecha en Madrid 2001, con un estudio de Vidal González Sánchez, con la colaboración del Instituto de Historia "Isabel la Católica" y el arzobispado de Valladolid.

77. Ibid., ed. por Gonzálezpp. 41-44 y 47-52, donde aparece el Codicilo. El original se encuentra en la Biblioteca Nacional de Madrid, Ms. Vit. 6-6, (Signatura antigua, tomo 301 del que procede) ff. 195-198, que tenía antes de ser separado en 1881. Posteriormente fue foliado del 1 al 4.

78. Silio CoRTÉs, César, Isabel la Católica, p. 492. 
en funerales suntuosos. Manifestó su deseo de ser enterrada en el monasterio de San Francisco, que estaba en el Alhambra de la ciudad de Granada, donde esperaba le hiciese compañía su esposo con esta observación: "pero quiero e mando que si el Rey, mi Señor, eligiere sepultura en otra cualquier iglesia o monasterio de cualquier otra parte o lugar de estos reynos que mi cuerpo sea allí trasladado e sepultado junto con el cuerpo de Su Señoría, porque el ayuntamiento que tuvimos viviendo e que nuestras ánimas, espero en la misericordia de Dios, ternan [tengan] en el cielo, lo que tengan o representen nuestros cuerpos en el suelo"79. Tuvo también para su esposo frases muy cordiales, como la siguiente: "Suplico al rey mi Señor que se quiera servir de todas las joyas e cosas, o de las que Su Señoría más agraden; porque viéndolas pueda haber más continua memoria del singular amor que a Su Señoría siempre tuve; e aún porque siempre se acuerde de que ha de morir; e que le espero en el otro siglo; e con esta memoria pueda más santa e justamente vivir" 80.

\section{c) Recomendó a su esposo y a los príncipes que prosiguiesen la evangeli- zación}

Se preocupó de la sucesión en el trono, rogando a su esposo que aceptase la regencia, respetando los derechos de la Corona de Castilla a la que pertenecían las Islas Canarias y tierras de América: "Otrosí, por quanto las Yslas y Tierra Firme del mar Océano e yslas de Canaria, fueron descubiertas y conquistadas a costa de estos reynos mios e con naturales de ellos, e por eso es razón que el trato y provecho de ellas se haya e trate e negocie de estos mis reynos de Castilla e de León e en ellos venga todo lo que de allá se taxiere; por ende, ordeno e mando, que así se cumpla, asi en las que hasta aquí son descubiertas como las que se descubrieren de aquí adelante, e no en otra parte alguna"81. Justificó la pertenencia "del reino de Granada, Canarias, demás Islas y Tierra Firme descubiertas y por descubrir a Castilla y León, según que en la bula apostólica a nos sobre ellos concedida se tiene" 82 . Se refiere a la bula Inter coetera de Alejandro VI, que estaba apoyada por la doctrina de la Cristiandad medieval con la llamada potestad indirecta. El papa podía intervenir por razón de lo espiritual para evangelizar. D. Fernando debía de actuar como gobernador en defecto de $\mathrm{D}^{\mathrm{a}}$ Juana, si ella no estuviese en estos reinos o estuviese impedida, como ella dice "hasta en tanto que el infante D. Carlos, mi

79. Testamento, edic. por la Dirección General de Archivos en 1969, p. 26 [f. 1v].

80. Ibid., p. 36 [f. 8 r]

81. Ibid., p. 31 [f. 5 r]

82. Ibid., p. 33 [f. 6v]. 
nieto, hijo primogénito heredero de los dichos Príncipe e Princesa sea de edad legítima, a lo menos de veinte años cumplidos, etc. "83.

Les recomienda a su hija $D^{a}$ Juana y a su yerno Felipe el Hermoso que sean fieles a la Iglesia y prosigan la conquista y evangelización de África con estas palabras: "Ruego e mando a la dicha Princesa mi hija, e al dicho Príncipe, su marido, que como Cathólicos Príncipes, tengan mucho cuidado de las cosas de la honra de Dios e su sancta fe, celando e procurando la guarda e defensión e ensalzamiento della, pues por ella somos obligados a poner las personas e vidas, e lo que tuviéramos, cada que fuere menester, e que sean obedientes a los mandamientos de la Sancta Madre Iglesia e protectores e defensores della, como son obligados, e que no cesen de la conquista de África e de pugnar por la fe contra los infieles"84. Hace recomendaciones a los príncipes y al rey para que vivan en concordia y administren rectamente los reinos, respetando las libertades, fueros y buenos usos y costumbres, que tenían las ciudades, villas y lugares de sus antepasados. Establece recompensas para los servidores reales, orden de sucesión en el reino y legados de joyas y reliquias, nombramiento de testamentarios, etc. Luego añade: "Cumplido este mi testamento e cosas en él contenidas, mando que todos los otros mis bienes muebles que quedaren, se den a las iglesias e monasterios para las cosas necesarias, al culto de Santo Sacramento e las cosas que a mis testamentarios pareciere. $E$ así mismo se den a hospitales y pobres de mis Reynos, e a criados míos, si algunos hubiese pobres, como a mis testamentarios pareciere" 85 .

Aunque este Testamento se redactó y firmó el 12 de octubre de 1504, no cabe duda de que había sido meditado y preparado de antemano, al menos en parte. Luego siguió reflexionando sobre el cumplimiento de sus obligaciones para ver si se había olvidado de algunos deberes atando bien los cabos de sus cláusulas. Por eso, el 23 de noviembre, próxima ya su agonía, tres días antes de morir, estableció en un Codicilo adicional que aún le quedaban algunas dudas sobre la legalidad del impuesto de alcabala, por lo que manda a sus herederos averigüen bien su origen y legalidad, y "si necesario fuere hagan luego jurar Cortes, e den en ellas orden qué tributos se deban justamente imponer en estos mis Reynos, para sustentación del dicho Estado Real dellos, con beneplácito de los dichos mis Reynos, para que los Reyes que después de mis días en ellos reinasen, lo puedan llevar justamente" 86 . No se podía olvidar de sus vasallos queridos, los indios del Nuevo Mundo, por lo que encargó y orde-

83. Ibid., p. 32 [f. 5v].

84. Ibid., p. 32 [f. 6r].

85. Ibíd., p. 36 [hoja 8r].

86. Ibid., p. 43 [f. 2v] 
nó al Rey y Príncipes, sus sucesores que pusiesen toda diligencia para no permitir que los naturales y moradores de las Indias y Tierra Firme, ganadas y por ganar, recibiesen agravio alguno en personas y bienes, sino que fuesen bien y justamente tratados, y si algún agravio hubiesen recibido, que lo remediasen y proveyeren: "Item, por quanto al tiempo que nos fueron concedidas por la sancta Sede Apostólica las Yslas e Tierra Firme del Mar Océano, descubiertas e por descubrir, nuestra principal intención fue, al tiempo que lo suplicamos al papa Alejandro sexto, de buena memoria, que nos hizo la dicha concesión, introducir e traer los pueblos dellas e les convertir a nuestra sancta fe cathólica, e enviar a las dichas Yslas e Tierra Firme prelados e religiosos e clérigos e otras personas doctas e temerosas de Dios para instruir los vecinos y moradores dellas en la fe cathólica, e les enseñar y doctrinar buenas costumbres, e poner en ellos la diligencia debida, según más largamente en las letras de la dicha concesión se contiene, por ende suplico al rey mi señor muy afectuosamente, e encargo e mando a la dicha princesa, mi hija, e al dicho príncipe, su marido que así lo hagan e cumplan, etc." 87.

\section{Muerte de Isabel, como hija de la Iglesia, y cómo fue llevado su cadáver a Granada}

La Reina, según la Crónica de Pulgar, "estuvo por espacio de cien días continuos de enfermedad fatigada"88. La atendió en los últimos días como confesor, fray Pedro de Béjar, monje jerónimo, prior del monasterio de La Mejorada. Mientras el Dr. Pedro de Oropesa daba forma jurídica al Testamento, fue llamado a palacio fray Pedro de Béjar, que se quedaba muchos días en una residencia que se le habilitó en Medina del Campo, para estar cerca del Palacio Testamentario, según consta en el Libro Becerro de La Mejorada, donde se afirma lo siguiente: "Con esto se pasó hasta últimos de noviembre [en] que murió la Reyna, aviéndola asistido fray Pedro, hasta que espiró y la dio la Unción... De alli a los pocos días, le postularon para Prior de la casa de Yuste y se fue" 89 .

87. Ibíd., p. 42 [f. 2r]. Cf. Romeu ARmAs, Antonio, La política indigenista de Isabel la Católica, Valladolid 1969, pp. 401-402.

88. Silıo CoRTÉs, César, Isabel la Católica, p. 491.

89 Biblioteca del colegio de Santa Cruz, Valladolid, "Libro Becerro de la Mejorada", sig. 258. Se agradece a D. Vidal González Sánchez la facilitación de este dato y otros sobre el Proceso de Canonización. El acompañó a D. Vicente Rodríguez Valencia como secretario en el Proceso y en los trabajos de la Comisión. 


\section{a) Recepción de la extremaunción y última estancia de Isabel en Medina del Campo}

Se le administró la Unción o Extremaunción, según la costumbre y el Ritual o Sacramentario de la época, con asistencia de los fieles, que pedían por su salud, y de los cortesanos, entre los que estaba su esposo, el rey D. Fernando, con las candelas encendidas en las manos. Se hacían las unciones en los sentidos: vista, oído, gusto, olfato, etc. Se le ungieron las manos ciertamente y los pies; pero pidió no se la hiciese la unción que a los hombres se les hacía en los lomos y a las mujeres en el ombligo. Como afirma Vidal González Sánchez, carece de fundamento la afirmación de que se negó a que le ungiesen los pies. El reparo que formuló como un ruego, nunca con negativa oposición, fue debido a la enfermedad que padecía y a la presencia de tantos asistentes, que ofrecía dificultades por lo que llegó a ser omitida esta unción ${ }^{90}$.

Uno de los que asistieron y presenciaron los últimos momentos y la muerte de Isabel la Católica no fue el P. Agustín Faccioni de Interamna o de Terni, Vicario General de la Orden Agustiniana, como afirma el P. Zacarías Martínez; debió de ser el P. Juan Bautista de Nápoles, que era Vicario y Visitador General. Estaba promoviendo la reforma de los conventos de la Corona de Aragón y también la observancia en el de Valladolid. Acompañaba a los Reyes Católicos en Medina del Campo ${ }^{91}$. Si Martín de Córdoba orientó a Isabel en los momentos decisivos de su vida como legítima heredera al trono de Castilla y de León, otro agustino, junto con algunos religiosos, obispos y sacerdotes, la acompañó y orientó en los momentos finales de su vida. Conocía las virtudes de la reina Isabel la Católica, que había pasado exactamente 811 días en Medina del Campo. La última estancia en Medina fue de 331 días desde el 1 de enero hasta el 26 de noviembre de 1504. Murió Isabel la

90. GonZÁLEz SÁNCHEZ, Vidal, Isabel la Católica y su fama de santidad, p. 127; Medina del Campo en la vida y muerte de Isabel la Católica. Conferencia en el 490 aniversario de su muerte, Medina del Campo, 26 de noviembre de 1994, ff. 23-25, donde se menciona al Sacramentario de D. Pedro de Toledo, que era usado en aquella época. Se considera como causa de la muerte la del cáncer de útero, verecundus ulcus del que habla Marineo. Se trataba de una llaga o úlcera púdica (maligna). Los informes de los médicos doctores, Soto y Julián, que atendían a la Reina eran alarmantes ya en 20 de junio de 1503. Cf. BlanCo SÁnCHEZ, Antonio, Sobre Medina del Campo y la Reina agraviada, Medina del Campo 1994, pp. 82-83. Mandaban quemar su carta, que se conservó.

91. MARTíneZ, Zacarías, Oración fúnebre, p. 12, nota 1; ARAmburu, Ignacio, "El Capítulo toledano de 1504 fin de la Claustra en la Provincia de España", Archivo Agustiniano, 57 (1963) 70-71 y 83-90; GARCía ORO, José, La reforma de los religiosos, p. 116. GutiéRrez, David, Historia de la Orden de San Agustín. Los Agustinos en la edad media 1357-1517, 1/2, Roma 1977, p. 36. Había muerto el P. General Graciano Ventura. 
Católica como fiel hija de la Iglesia al filo del mediodía ${ }^{92}$. Se conserva todavía una parte valiosa del llamado Palacio Testamentario, con un patio interno, donde se inauguró el 26 de noviembre de 2003 un Centro de Interpretación de la Reina, que consta de tres salas: una dedicada a su vida y dos al Testamento y muerte con el cuadro de Luis Rosales. Se sabe que murió en una habitación del cuarto patio, hacia la huerta del poniente, donde. se hicieron excavaciones a finales del siglo XX y comienzos del XXI. Se podía precisar el lugar de las dos cocinas, de la panadería y de otras piezas nobles como la capilla real, el comedor y la sala grande del trono que tuvo artesonado mudéjar ${ }^{93}$.

\section{b) Anuncio oficial de la muerte santa de Isabel la Católica y sufragios por} su alma

El rey D. Fernando alzó los pendones en la plaza de Medina del Campo, como Gobernador por su hija $\mathrm{D}^{\mathrm{a}}$ Juana, Reina de Castilla y León, el mismo día 26 de noviembre de 1504 por la tarde. Luego a la luz de las velas comunicaba sus sentimientos a Gaspar de Gricio para que diese la noticia oficial de la. muerte de su esposa con estas palabras: "aunque su muerte es, para mí, el mayor trabajo que en esta vida me pudiera venir, y por una parte el dolor de ella y por lo que en perderla perdí yo y perdieron todos estos reinos, me atraviesa las entrañas, pero por otra, viendo que ella murió tan santa y católica como vivió, es de esperar que Nuestro Señor la tiene en la gloria, que es para ella mejor y más perpetuo reino que los que acá tenía". Mandó luego la noticia de la muerte santa de la Reina por correo a uña de caballo a las distintas ciudades y villas, como a Valladolid, a donde llegó el mismo día 26 por la noche y se conoció a primeras horas de la mañana el 2794 .

92. Dr. Toledo, "Diario del", en Cronicón de Valladolid, p. 219. Cf. GonZÁlez SÁnCHEZ, Vidal. Isabel la Católica y su fama de santidad, p. 178, donde se cita la documentación existente en el Archivo de Simancas. Si se agrupan todas las estancias de Isabel la Católica en Medina del Campo forman 27 meses, es decir, cerca de novecientos días en su querido hogar, el llamado Palacio Testamentario, incluyendo las breves estancias que hizo en las habitaciones del Castillo de la Mota, al que visitó el 1 de enero, cuando volvía muy enferma de Segovia, para convencer a su hija Juana que se fuese a Flandes. A los 811 días hay que sumar los días que cruzó y deambuló por Medina del Campo con motivo de sus desplazamientos por lugares cercanos como $\mathrm{La}$ Mejorada, El Abrojo, Madrigal, Arévalo, etc.

93. AGS, Corona y Sello Real, leg. 5, pieza 5, Leg. 46, pliego, 2, Leg. 4, etc. En lo poco que queda del Palacio Testamentario hay una exposición en el V Centenario de la muerte de Isabel la Católica.

94. Archivo de la Real Chancillería, Valladolid, Libro de Acuerdos, I, ff. 14-18 y 59, donde se deja constancia de que "a boca de noche vino la nueva cómo la Ylustrísima Señora Reyna Do- 
Entre los 41 monasterios a los que se enviaron limosnas de 5.000 maravedíes para que se tuviesen sufragios por su alma estaba el de San Agustín de Burgos al que fue enviado un capellán para que llevase el donativo al Santo Cristo, del que ella quiso quedarse con un clavo95.

Según el P. Enrique Flórez en su tumba deberían escribirse estas palabras, que el autor de los Proverbios dirige a la mujer que teme al Señor: ipsa laudabitur, que quiere decir: por sí misma será alabada"96. Se la rindieron los honores fúnebres en Medina del Campo por orden de su esposo. D. Juan de Medina, obispo de Segovia, abad de la colegiata y presidente de la Real Chancillería reunió en la mañana del 27 a todos los oidores, alcaldes, regidores, nobles y plebeyos para acordar el modo de hacer los funerales el día 29. A mediodía del 26 de noviembre, cuando murió la Reyna a la edad de 53 años, siete meses y tres días, se encargó de acondicionar el ataúd un carpintero llamado Jerónimo de Palacios, experto en labores mudéjares, moro converso y muy fiel a los Reyes Católicos. Se dan detalles de que el ataúd estaba "enforrado de cuero encerado". Se hizo además "una cama alta para sentar las andas, que costó todo novecientas e setenta maravedies" 97.

Como si estuviese presente en aquel luctuoso momento, el P. Zacarías Martínez, con motivo del IV Centenario de su muerte, dio testimonio de sus virtudes en su Oración fúnebre, el 26 de noviembre de 1504, afirmando lo siguiente: "¡Españoles que me escucháis: hijos de Medina del Campo, que conserváis los recuerdos más gratos de aquella excelsa Reina, porque aquí dio principio a la carrera de sus glorias inauditas y aquí las coronó con el triunfo más grande que puede tener un alma cristiana: con la gracia de la perseverancia final en su santa muerte" 98 . El P. Zacarías Martínez afirma también que después de redactar su incomparable Testamento con su Codicilo y de recibir "los auxilios de la Iglesia, pan de los fuertes que van camino de la eternidad,..

ña Ysabel de gloriosa memoria, hera fallesçida en Medina del Campo dycho día a medio dya, la qual muryó de hedad de çinquenta e tres años e syete meses e tres días.." Vidal González considera "a boca de la noche" como amanecer del 27, día en que se levantó el acta. GonZÁLEZ SÁNCHEZ, Vidal, Medina del Campo en la vida y muerte de Isabel la Católica, f. 27. El mismo autor hizo su tesis doctoral sobre Documentos de la época de los Reyes Católicos en el Archivo Catedral de Málaga o la constatación de una política integradora, intramuros de la ciudad de Málaga (14511516). Ha publicado la obra Málaga. Perfiles de su historia en documentos del archivo catedral (1487-1516), Málaga 1995. Se le agradece la facilitación de esta obra.

95. AGS, Casas y Sitios Reales, leg. 45, f. 77. FLÓREZ, Enrique, España Sagrada, 27, Madrid 1772 , p. 497.

96. Proverbios, 31, 30 sobre la "perfecta ama de casa". Flórez, Enrique, Memorias de las Reinas Cathólicas, II, Madrid 1790, p. 844.

97. AGS, Casa y Sitios Reales, leg. 5, pieza 5, f. 369. No llegó a 29 reales de los de entonces. 98. MARTíNEZ NúNEEZ, Zacarías, Oración fúnebre, pp. 11-12. 
inclina la cabeza, aquella cabeza que sostenía la corona más hermosa del mundo y entrega su espíritu en manos de Aquel por quien vivió, luchó y venció".

"Murió, Señores, exclama el P. Zacarías Martínez, en Medina del Campo; se apagó la estrella de Castilla, tendió sus alas el ángel para volar a los cielos; España perdió su gran felicidad y la Religión a la gran amadora de la virtud"99. Añade testimonios como el de Pedro Mártir de Anglería, que la consideró "modelo de toda virtud" y de los que presenciaron su muerte o la trataron para concluir con estas palabras: "Yo hablé de ella como pude hablar de una santa". Acata el juicio de la Iglesia y añade: "tengo la convicción de que tu sierva Isabel goza ya de las venturas celestiales, que tienes preparadas, desde el principio del mundo para las almas justas" 100.

En Madrigal afirmé al recordar el 405 aniversario de la muerte de fray Luis de León, que "era un genial poeta con dotes de gobernante". Y que allí, en Madrigal, había nacido "una Reina digna de los altares"101. Aunque en el testamento afirma que quiere "que sin detrimento alguno, fuere llevado mi cuerpo entero como estuviere a la çibdad de Granada",102 no siempre se cumplía ese deseo. Era una praxis normal en aquella época cuando se hacía traslado de cadáveres, como sucedió con fray Luis de León. Es posible que en Medina del Campo quedase el corazón de la Reina, que tanto había amado, junto con otras partes internas de su cuerpo. Se solían enterrar en la huerta o jardín.

c) Cómo fue llevado su cadáver a Granada con cierta veneración de los fieles

Cumpliéndose con su deseo testamentario de ser enterrada en Granada, Fernando el Católico o de Trastamara, como lo era también Isabel, se tuvieron preces y llantos, como los ha habido pocas veces en Castilla, especialmente en Medina del Campo, donde se tuvo una primera misa de corpore insepulto en el oratorio de la casa-palacio. Se dispone de la nómina de los que intervinieron en el traslado del cadáver desde Medina del Campo hasta Granada ${ }^{103}$ con el sueldo que cobraron los 177 acompañantes de la comitiva,

99. Ibíd., pp. 55-56.

100. Ibíd., pp. 56 y 65.

101. CAMPo DEL Pozo, Fernando, "Adaptación del Derecho y la poesía a un mundo moderno por fray Luis de León en el siglo XVI", Revista Agustiniana, 39 (1997-1998) 83.

102. TORRE Y DEL CERro, Antonio de la, Testamentaría de Isabel la Católica, Valladolid 1968 , p. 449.

103. Silio CoRTÉs, César, Isabel la Católica, pp. 491-492. 
entre miembros de Capilla, cantores, capellanes, mozos de la misma, reposteros, etc. Lo que se gastó a la vuelta con todos los oficiales fue un coste total de $380.000 \mathrm{mrs} .{ }^{104}$. Se conocen las peripecias del camino, donde se puso de manifiesto el amor que tenían a la Reina por sus grandes virtudes y fama de santidad. Había sido fiel hija de la Iglesia105.

Aunque se hicieron los preparativos el mismo día 26, no salieron ese día, sino día 27 por la mañana, mientras D. Juan de Medina acordaba hacer solemnes funerales. Estaban los restos mortales de la Reina Católica revestidos de austero hábito franciscano, en el ataúd "enforrado de cuero encerado", como se ha observado anteriormente. Lo había confeccionado Jerónimo de Palacios ${ }^{106}$, junto con las andas para ser transportado por sus fieles criados y camareros. Iban con otros fieles servidores de la corte bajo las órdenes de Pedro Patino. Sufriendo las inclemencias del tiempo y las tormentas, llegaron el primer día a Arévalo, donde había pasado su infancia y tenía muchos admiradores. Pasó la noche en el cenobio franciscano, con acompañamiento de rezos y sollozos. Se celebraron varias misas al amanecer y después de la misa mayor y un responso siguieron el camino, no sin antes preparar dos collarines de terciopelo para las acémilas que portaban las andas. Llevaban un paño rico de brocado con el que se cubría el féretro en los lugares de posa, donde se rezaba un responso.

Siguieron por el Bohondón y Gotarrendura hasta Cardeñosa, donde había muerto el príncipe Alfonso, su querido hermano. Siguieron hasta Ávila y luego a Cebreros, donde se hizo posa de noche y treinta braceros tuvieron que ayudar a vadear el río Alberche que había crecido. Recibía honores especiales al llegar a las ciudades, como sucedió en Toledo, donde caballeros y regidores tomaron a hombros el ataúd frente a la Puerta del Cambrón para rezar un responso y llevar el ataúd hasta San Juan de los Reyes. Siguieron a Manzanares, Torre del Campo, Jaén, Viso del Marqués y Menjíbar, donde utilizaron una barca para pasar el Guadalquivir. Después de veintitrés días llegaron los restos de la fundadora y fundidora de España y madre de América a Granada, donde fueron recibidos por el Arzobispo Talavera y el Capitán General y Conde de la Tendilla. Se hicieron solemnes funerales desde el 18 de diciembre hasta el 23, depositándola en la iglesia de San Francisco o Santa Isabel como un tesoro ${ }^{107}$. En su primera sepultura llana aparecía $D^{a}$ Isabel I,

104. A.G.S., Casa Real de Castilla (O y B) leg. 4, f. 8, y leg. 10 f. 18.

105. A.G.S., Obras y Bosques, Leg. 8, ff. 437-438. Cf. TORRE y DEL CERro, Antonio de la, Testamentaría de Isabel la Católica, Valladolid 1968, pp. 438-431; GONZÁlez SÁNCHEZ, Vidal, Isabel la Católica y su fama de santidad, pp. 185-191.

106. A.G.S., Casa y Sitios reales, leg., 5, pieza 5, f. 369.

107. A.H.N, leg. 3.406, f. 101. 
la Católica, muerta en 1504, y en la de su esposo, Fernando de Aragón, en 1516 , hasta que fueron puestos en sendos monumentos sepulcrales en la Capilla Real de la catedral de Granada. El túmulo del sepulcro real fue labrado por Domenico Fancalli, que falleció en 1519. Aunque la orden de traslado fue dada por el Emperador Carlos V en 1520, se realizó en 1521 desde la humilde sepultura de San Francisco hasta la Capilla Real de Granada108.

El 9 de junio de 1972 se hizo el reconocimiento del sarcófago de la Reina, sin abrirlo, porque no era preceptivo en el Proceso Ordinario, "con arto sentimiento", ya que se había hecho con motivo del V Centenario del nacimiento de Isabel la Católica en 1951109.

\section{6) Estado del proceso de canonización y el cuadro de Ntra. Sra. de la 0 de Otengá}

Aunque historiadores de su época y quienes trataron a la Reina Isabel resaltan sus virtudes, como lo constatan Jerónimo de Zurita y el P. Juan de Mariana, fue en el siglo XVIII, cuando se dio un toque de alerta por D. Santiago Riol, archivero del reino en tiempos de Felipe V, al sorprenderse por qué no estaba canonizada. Sus investigaciones fueron continuadas por el $\mathrm{P}$. Enrique Flórez, Diego de Clemencín y Modesto Lafuente que, siendo liberal, no comprendía cómo no estaba esta Reina en la nómina de los elegidos o de los santos.

El P. Zacarías Martínez se alegró cuando entre los años 1924 y 1929, el arzobispo de Granada, cardenal Casanova, hizo una consulta a la Corte y a la Santa Sede para la introducción de la causa. Ésta se encomendó al arzobispo de Valladolid, R. Gandásegui que, en 1929, intentó dar los primeros pasos para introducir la causa a petición del Congreso Mariano Iberoamericano celebrado en Sevilla110. Se intentaron dar algunos pasos incluso durante la Segunda República Española, pero de hecho no se inició hasta el 23 de abril de 1958, siendo arzobispo Mons. José Goldáraz.

108. Gallego y Burín, Antonio, La Capilla Real de Granada, Granada 1931, p. 197; GonZÁlez SÁNcheZ, Vidal, El Testamento de Isabel la Católica, pp. 229-232.

109. Reina Católica, Boletín de la Causa de Beatificación de la Reina Isabel I de Castilla, Valladolid, n. 13, enero de 1973, p. 32.

110. El Debate, 14 de junio de 1929, p. 1, donde aparece una editorial de Ángel Herrera Oria, luego obispo de Málaga y cardenal, que está en proceso de canonización. Herrera Oria consideró a la Reina Isabel, "como la patrona de la raza... para todos los católicos de España y 


\section{a) Cómo se inició el proceso de canonización de Isabel la Católica}

Ya en 1957 se había hecho una consulta previa al cardenal Cicognani, prefecto de la Sagrada Congregación de Ritos y luego nuncio en España. Se habían recibido muchas peticiones de España, Hispanoamérica, Filipinas y NorteAmérica. Se promovieron estudios críticos y serios por el Pbro. Dr. Vicente Rodríguez Valencia, canónigo-archivista, al que se nombró postulador de la causa y fue el "alma de esta empresa", como se afirma en la. "Positio" sobre los escritos, donde se deja constancia de que el 3 de mayo se nombró una comisión histórica con tres especialistas de historia medieval. Se añaden nuevos miembros: el 23 de septiembre se nombra al Dr. Luis Suárez Fernández; al Dr. Mons. Demetrio Mansilla, obispo de Ciudad Rodrigo, el 30 de junio de 1970; y al P. Quintín Aldea, S.J., el 21 de mayo de 1970. Seleccionaron 2.864 documentos en 26 tomos y dieron su primer informe el 20 de junio de 1970 en 14 páginas donde afirman lo siguiente: "Es dificil encontrar, al menos en la Edad moderna, un personaje, Real o particular, que haya dado tanta gloria a Dios y a la Iglesia como esta Sierva de Dios"111.

Con el motu proprio Sanctitas clarior de Pablo VI, del 19 de marzo de 1969 , se da una nueva ordenación de los procesos de beatificación, que se sigue para llevar la causa adelante. El Proceso ordinario diocesano se inició el 3 de julio de 1970 con la ayuda de D. Pablo Díez, español-leonés residente en Méjico. Se constituyó el tribunal el 26 de noviembre de 1971, siendo arzobispo Mons. Félix Romero Menjíbar, que nombró a Mons. José García Goldáraz, arzobispo dimisionario, juez delegado para llevar adelante el proceso con tres partes: $1^{\mathrm{a}}$ de diligencias, $2^{\mathrm{a}}$ sobre no culto y $3^{\mathrm{a}}$ la información sobre fama de santidad. Se clausuró el proceso el 15 de noviembre de 1972. Se llenaron 28 volúmenes. El Postulador revisó la Documentación con la Comisión Histórica desde diciembre de 1971 hasta febrero de 1972 para elaborar los Artículos, que llevan su firma de 7 de octubre de 1972112.

Vino luego el Proceso en Roma, donde fue nombrado postulador de la Causa el P. Anastasio Gutiérrez, eminente canonista que había llevado el proceso de canonización de San Antonio María Claret. Se presentó la documentación el 18 de noviembre de 1972 a la Sagrada Congregación "pro causis sanctorum" y se dio comienzo al Proceso el 20 de noviembre de 1972. Un teólogo censor da su opinión el 13 de enero de 1973 con algunas dificulta-

111. Positio super scriptis, Roma 1973, pp. 9 y 18-19. La Relación, que se presentó al Tribunal Diocesano el 21 de enero de 1972 tiene 252 pp. La historia de la causa aparece en la Positio, pp. 18-19, en Reina Católica y la Revista Isabel.

112. Rodríguez Valencia, Vicente, Artículos, pp. 3-4. 
des ${ }^{113}$ y otro el 22 de abril de 1973 , donde concluye con un elogio y símil con santa Teresa, que había hecho Palafox: "Hice concepto que eran tan parecidos estos naturales y espíritus..., que si la Santa hubiera sido Reina, fuera otra Católica Doña Isabel; y si esta esclarecida princesa hubiera sido religiosa-que bien lo fue en virtudes-, fuera otra Santa Teresa"114.

En los Artículos del Postulador va apareciendo la vida de Isabel la Católica, desde su nacimiento en Madrigal de las Altas Torres el 22 de abril de 1451, pasando por su infancia en Arévalo, su formación, vida de oración, Pacto de Guisando del 18 de septiembre de 1468; capitulaciones matrimoniales con Fernando de Aragón, 7 de enero de 1469; proclamación de Reina de Castilla y León en Segovia, el 13 de diciembre de 1474, plan de vida, virtudes en grado heroico de fe, fortaleza, prudencia, paciencia, templanza, humildad, caridad, justicia, castidad, etc., hasta su muerte en Medina del Campo el 26 de noviembre de 1504, cuando tenía "cincuenta y tres años de edad"115. En los artículos del Proceso aparece la mejor vida de Isabel la Católica con sus luces y sombras que le dan colorido y belleza, como una buena cristiana, cumplidora de sus obligaciones y fiel hija de la Iglesia.

\section{b) Testimonios sobre la vida y virtudes de Isabel la Católica}

Hay muchos testimonios de testigos oculares y de historiadores, que constituyen la mejor biografía y perfil de Isabel la Católica. A los Artículos de la fama de santidad, vida y virtudes de la sierva de Dios Isabel I, Reina de Castilla, que propone el postulador de la causa, Dr. D. Vicente Rodríguez Valencia en Valladolid, el 21 enero de 1972116, siguen otros sobre "no culto" a la sierva de Dios, que se concluyen el 25 de febrero de 1972117. Se juntaron 28 tomos a los que se añadieron 14 más hasta completar el número de 42 . El 13 de junio de 1973 se concluye el proceso histórico, es decir, super scriptis. El material recogido por D. Vicente Rodríguez Valencia, que murió el 8 de mayo de 1982, sirvió para la Positio redactada por el P. Anastasio Gutiérrez (claretiano) y D. Justo Fernández, rector de la iglesia española de Montserrat, en

113. Positio, pp. 46-48, donde aparece la palabra "venganza" en la toma de Barcelona el 3 de noviembre de 1472; sobre el párrafo 12 del Testamento, donde trata de la reducción de los oficiales que habían sido aumentados en su reinado "de lo cual ha redundado y redunda daño" y el párrafo 13 , donde se hace "anulación de mercedes, no voluntariamente concedidas y que se relacionaban con una carta ajena al testamento".

114. Ibíd., pp. 17 y 60.

115. Ibíd., pp. 7-51.

116. Ibíd., p. 66.

117. Ibid., p. 77. 
Roma. Colaboró el P. José María Gil, también cleretiano, como vicepostulador.

El 12 de mayo de 1983 fue aprobado el proceso histórico, "super scriptis". Después de un compás de espera de siete años, en 1990, el arzobispo de Valladolid, Mons. José Delicado Baeza, ante el V Centenario del descubrimiento y evangelización de América, consultó a la Comisión Permanente de la Conferencia Episcopal Española el 5 de julio, sobre "la oportunidad de tomar alguna iniciativa a favor de esta Causa". El 6 de noviembre de 1990, la Congregación de las Causas de los Santos aprueba el proceso histórico y el 6 de diciembre se aprueba el proceso diocesano de Valladolid.

Mons. José Delicado Baeza, el 4 de abril de 1991, envió una carta a todos los obispos españoles pidiéndoles su adhesión con unas notas biográficas preparadas por D. Luis Suárez Fernández. En nombre de la Conferencia Episcopal Española, dio su apoyo el cardenal Ángel Suquía Goicoechea con una carta dirigida al Papa el 3 de febrero de 1993. En 1994 dieron su apoyo el arzobispo de Santo Domingo y el Presidente de CELAM, a petición del arzobispo de Valladolid, que volvió a insistir ante el papa el 22 de mayo de 1997118.

La Positio estaba concluida para 1991 y se pensaba obtener la aprobación de las virtudes y la declaración de "venerable", como paso previo a la beatificación para el año de 1992. Se había obtenido la aprobación histórica por la Comisión Histórica en reunión del 6 de noviembre de 1990, como se ha observado anteriormente, y se pasó a la Comisión Teológica. Se tiene noticia de que sus miembros ya han emitido su parecer. Si su juicio resulta favorable y se rumorea que sí lo es, se pasará a la Congregación de prelados y cardenales, la cual dará su parecer al papa, a quien está reservada la decisión sobre la heroicidad de las virtudes y la declaración oficial como "venerable". No conviene que el proceso se pare o detenga, aunque puede haber motivos para un compás de espera119.

D. Vicente Rodríguez Valencia había escrito una biografía o semblanza en 1961 y luego recogió, como preparación de la Positio, la opinión de los españoles y extranjeros sobre Isabel la Católica y su caridad con los pobres, llegán-

118. Comisión "ISABEl la CATólicA", Causa de canonización de Isabel la Católica, Arzobispado de Valladolid 2001, sin paginar. Correponde a las pp. 4-5.

119. La nueva Positio se concluyó e imprimió en Valladolid el 22 de abril de 1991. El Pbro. José Flaviano Ramírez, que fue canciller y secretario de la curia diocesana ha informado sobre el iter de la causa en los años 1980-1992. Ha quedado paralizada o con un compás de espera hasta el 2002. Colaboró mucho el P. José Ma. Gil, autor de una buena biografía titulada Misterio de Isabel la Católica, Madrid 1992, 408 pp. con valiosos cuadros e imágenes de los Reyes Católicos en los billetes del Banco de España de 1.000 pts. 
dose a tener noticia de 140 intervenciones caritativas de esta samaritana. Uno de sus Consejeros de Estado vio que "daba limosnas con largueza a todas las Ordenes mendicantes, a los pobres de Cristo, a todos los necesitados"120.

\section{c) Artículos de la Positio sobre no culto y los cuadros de la Virgen con su rostro}

Interesan algunos Artículos, "sobre no culto" porque, en los arts. 15-20, se trata de retratos y cuadros de la Sierva de Dios en pinturas de la Santísima Virgen dedicados al culto público. Se observa que "contemporáneamente fue del gusto de pintores poner las facciones de la Reina en pinturas de la Virgen destinadas al culto. Ejemplo destacado de ello es el retablo del oratorio de la Reina, que ella encargó a Juan de Flandes: la tabla que representa a la Virgen María con los doce apóstoles en la venida del Espíritu Santo, tiene las facciones de la reina, con gesto de doloroso recogimiento, como respondía a los últimos años de la vida de la Reina. Todos estos pintores trabajaron en la Casa Real en los últimos años del siglo XV; Juan de Flandes, hasta la muerte de la Reina".

"Ahora bien -concluye D. Vicente Rodríguez Valencia-, ninguna de estas representaciones tiene signos, ni atribuciones, ni finalidad de culto " a la Reina121.

Se mencionan los cuadros existentes en la ciudad de Quito, Ecuador, como el de la Colección Lasso de la Vega, el de la Colección del Excmo. Sr. D. Carlos Manuel Larrea y el del Museo Jijón-Caamaño, donde aparece Isabel la Católica con nimbo y rayos en la cabeza. Hay otro en la Colección Gangotena Mancheno de Quito, con representación de la Virgen del Carmen a cuerpo entero, con corona y aureola. Se trata de un cuadro grande de Isabel la Católica, que probablemente fue "repintado por las monjas [del convento de la Concepción] para darle una representación mariana". Añade que "un ejemplar de este núcleo, o familia, de efigies con nimbo, de Quito, se encuentra en el Museo de la Fundación Lázaro Galdiano de Madrid, adquirida por este gran coleccionista español y depositada en su Museo"122. Se trata de una tabla con la coronación de la Virgen, pintada al óleo, temple, estilo gótico de 107,9 x 101,1 cms., con la cara de Isabel la Católica. Es de finales del siglo XV, atri-

120. RodRÍGUEZ VALENCIA, Vicente, Isabel la Católica en opinión de españoles y extranjeros. I, Valladolid 1970, p. 241. Esta obra está compuesta de 3 vols. Anteriormente había escribo Semblanza textual de Isabel la Católica, Valladolid 1961.

121. Ibíd., pp. 73-74.

122. Ibíd., p. 79. 
buida al Maestro de Teruel, escuela aragonesa/española, sin estudio especial $^{123}$.

De este cuadro afirma la escritora Dulce María Loynaz que "una tabla del siglo XV nos la muestra nimbada la cabeza por un alo de llamas semejante al que circunda el disco del sol, el astro-dios en los antiguos templos incaicos". "Algo de sol vio también el artista en ella, que le corona de fuego los cabellos"124. Hay otros cuadros de la Santísima Virgen en España con la cara de Isabel la Católica a la que se reconoce como venerable, como el lienzo de 100 x 90 cms., que se encuentra en la iglesia parroquial de Prádena (Segovia), de mediados del siglo XVI, con cortinaje y circundado de rosas, de autor anónimo ${ }^{125}$. Hay una efigie de Isabel la Católica con el rosario entre Santa Catalina y Santa Engracia en la fachada de la parroquia de Santa Engracia (Zaragoza), de Gil Morlanes entre 1507 y 1515.

Un cuadro muy semejante al existente en el Museo Lázaro Galdiano se encuentra en la iglesia de Otengá (Cundinamarca, Colombia). Tuve la oportunidad de verlo en 1992. Se trata de una pintura de Nuestra Señora de la O (Dolorosa) y Esperanza, con la cara de Isabel la Católica. Está pintada sobre tabla de 33 x $23 \mathrm{cms}$. Es ciertamente anterior a 1630 y pertenecía a $\mathrm{D}^{\mathrm{a}}$ Juana Dávalos Marín, que la llevó de España hacia 1615 y se la entregó al P. Pedro de Fuentes con una capilla y hacienda, donde se construyó un convento, bajo la advocación de Ntra. Sra. de Otengá, nombre del pueblo o vereda, como se dice en Colombia. Se nombró prior en 1630 al P. Lorenzo de Torres, como narra el benemérito historiador, P. José Pérez Gómez, según el cual, entre los santuarios marianos de Colombia, "ocupa un lugar distinguido el de Nuestra Señora de los Dolores de Otengá, llamado de la O, por la forma ovalada del cuadro en que se representa a la Virgen. Es una pintura de mérito, particularmente el rostro", etc. ${ }^{126 .}$

123. Inventario del Museo Lázaro Galdiano, Madrid, Sala de peines 1, peine 006. Se agradece a $\mathrm{D}^{\mathrm{a}}$ Carmen Espinosa, conservadora del Museo, la facilitación de estos datos.

124. LoYNAz, Dulce María, "El último rosario de la Reina", $A B C$, del 6 de noviembre de 1992, p. 1.

125. Se agradece a D. José Martín Sanz, que es de Prádena, el envío de una foto, cuyo pie de imprenta dice así: "Cuadro de la venerable Isabel la Católica que se encuentra en la Iglesia Parroquial de Prádena (Segovia). S. XVI. Anónimo"

126. PÉrez Gómez, José, "Apuntes para la Historia de la Provincia Agustiniana de Nuestra Señora de Gracia en Colombia", Archivo Histórico Hispano-Agustiniano, 23 (1925) 52-63; Cf. D. MuCientes Del CAMPO, Centurias colombo-agustinianas, Bogotá 1969, p. 59. Según fray E. Báez, O.P. la llevó Da Susana (Juana) Dávalos Marín que fue de España hacia 1615 y fue nombrada encomendera de Otengá en 1620 por D. Juan de Borja, Justicia mayor o Presidente de la real Audiencia de Santafé de Bogotá, "Noticia histórica de Nuestra Señora de la O de Otengá", en Novena a Nuestra Señora de la "O" de Otengá, Sogamoso 1936 y 1950, p. 3: 
No sé si el P. José Pérez Gómez, que revisó la documentación del Archivo de la Provincia de Nuestra Señora de Gracia en Colombia y habla de la forma ovalada del cuadro, llegó a verle; porque aparece claramente la cara ovalada de Isabel la Católica, sin hacer referencia a ella. Se prescinde aquí de la leyenda y tradición sobre cómo fue llevado este cuadro y cómo se tenía en gran estima y veneración, porque hacía muchos milagros en su capilla y los siguió haciendo luego en la iglesia del convento de los agustinos, centro polarizador de la religiosidad de aquella región, donde se han hecho más copias, como la que se venera en Morcá y difiere sólo por la corona, el velo, los pliegues del manto y el broche127.

Otro gran historiador, el P. Andrés de Mesanza, dominico, después de un breve relato de Nuestra Señora de Otengá o de la O en Beteitivá (Municipio y parroquia de Beteitivá, Departamento de Boyacá) tiene la siguiente adición: "¿María o Isabel? De María Santísima a Isabel $1^{a}$ de Castilla hay distancia casi infinita; pero todos, buenos y malos, creemos que la mujer del rey Fernando $V$ está en el cielo y en el corazón español y americano. Dice la tradición que una y otra imagen de Otengá y de Morcá son sacadas de un retrato de Isabel la Católica. No vemos ningún pecado en venerar a la Madre de Dios en un retrato de una Reina piadosa y buena, como el pan de trigo, máxime en este Nuevo Mundo, hijo en mucho de su inmenso corazón de madre"128.

De lo que sí puedo dar testimonio es que algunos del pueblo de Otengá saben que Ntra. Sra. de la $\mathrm{O}$ tiene el rostro de Isabel la Católica, algo que les agrada y les parece bien, porque esa Reina les quería mucho, se acordó de ellos antes de morir y les gustaría verla en los altares. Al estar la pintura sobre tela y madera, incrustada o pegada a una piedra hendida que le sirve de marco a la vez, con triple cristal y fuerte protección con maderos bien clavados, resultó difícil hacerle una buena foto en 1992 y luego en el año 2000.

Un pintor agustino, P. Nicéforo Rojo, al que le encargó hacer una copia un sacerdote salesiano de Otengá, en 1986, ha dado diversos testimonios, informando que el original no tiene rayos sino la corona adosada. Tenía una corona de oro según el inventario de 1740 y desapareció en el siglo XIX. Luego se puso una corona de hojalata con rayos dorados. El pueblo de Otengá no permite que se saque fuera. La copia hecha por el P. Nicéforo no

127. CAMPo del Pozo, Fernando, "Santuarios marianos en el Nuevo Reino de Granada", Provincia agustiniana de Nuestra Señora de Gracia en Colombia, II, Bogotá 1993, p. 571; y en Iconografía Agustiniana I, Roma 2001, pp. 610-612, donde se observa que tiene afinidad con ciertos iconos de la Virgen existentes en el antiguo Reino de Valencia; pero difiere de ellos en cuanto a la cara e indumentaria.

128. Mesanza, Andrés de, Célebres Imágenes y Santuarios de Nuestra Señora en Colombia, Chiquinquirá 1950, pp. 419-421, donde recoge el testimonio del Pbro. Joaquín R. Medina. 
tiene los rayos, porque tampoco los tiene el original. Una copia se encuentra en el Museo del Convento San Agustín de Bogotá129. En presencia de aquella imagen se siente la impresión de que la Reina Isabel ya está en los altares, aunque no se le venere aún, porque se espera el fallo definitivo de la Iglesia.

\section{Conclusión}

Isabel la Católica fue fiel hija de la Iglesia. Cumplió lo que le aconsejaron sus directores y formadores, como Martín de Córdoba, que la consideró en 1468 legítima heredera al trono de Castilla y de León, y futura reina de España. Le puso como modelo a la Santísima Virgen, a la que deben tener devoción "todos los fieles... en especial la señora Princesa, porque es de linaje real, como la Virgen que fue hija de reyes; y porque es doncella, como era la Virgen, cuando concibió al Hijo de Dios; y porque espera ser reina, como la Virgen que es Reina de los cielos, señora de los ángeles, madre de los pecadores y manto de todos los fieles" 130 .

Fue tan fiel hija de la Iglesia y de la Santísima Virgen que bien se merece ser tomada como modelo en sus pinturas, donde aparece su cara ovalada y con la expresión de una santa. No se comprende bien su actuación sin tener en cuenta las ideas de la Cristiandad medieval y su época con sus categorías canónico-jurídicas, además de filosófico-teológicas. Fue fiel hija de la Iglesia con especial acatamiento al Romano Pontífice. Promovió la reforma de la Iglesia en sus reinos, usando de la dispensa, de leyes especiales y de los privilegios pontificios para evangelizar, siendo ella modelo de la mujer cristiana y una reina santa con una intensa vida espiritual y "una constante aspiración a la perfección cristiana" 131 .

Después de haber visto la vida y proceso de Isabel la Católica, que fue fiel hija Iglesia y una reina digna de los altares, puede formularse una pregunta final: ¿Cómo está el proceso? La respuesta es que está terminado y aprobado en su parte histórica. Se le pueden hacer añadiduras y observaciones complementarias incluso para explicar su demora. Todo estaba listo para el año 1992. La presión de los judíos hizo que se diese un compás de espera,

129. Vallín Magaña, Rodolfo, Arte y fe. Colección artística agustiniana. Colombia, Santafé de Bogotá 1995, p. 59, n. 104. Se la denomina también Virgen de la Esperanza. Óleo sobre tela $(40 \times 30 \mathrm{~cm}$.)

130. CóRdobA, Martín de, Jardín de Nobles Doncellas, parte $1^{\text {a }}$, cap. 3, pp. 99-100. Se ha utilizado la edición hecha por el P. Félix García en Madrid 1956.

131. Rouco VArela, Antonio Ma ., "Reformadora de la Iglesia", p. 13. 
como sucedió con Edith Stein, que ya ha sido canonizada. Se esperaba para el año 2004.

Como se ha observado anteriormente, la Conferencia Episcopal Española, a petición del arzobispo de Valladolid actualmente emérito, Mons. José Delicado Baeza, acordó "insistir respetuosamente" ante el Papa para reanudar lo que se estancó en 1991 por razones de índole diversa, como sucede en esta clase de procesos. El problema de la expulsión de los judíos está ya superado, aunque haya opiniones discordes. Las posibles dificultades se estaban superando por el que era postulador P. Rafael $\mathrm{M}^{\mathrm{a}}$. Serra y actualmente por el P. Fernando Rojo, agustino, experto en la materia. La mayoría de los obispos de Hispanoamérica y de todos los católicos, incluso cristianos no católicos, están a favor de su posible canonización ${ }^{132}$.

A primeros de noviembre de 2002, D. Vicente Vara Sanz, Vicario General de la diócesis de Valladolid, el R. P. Rafael Ma. Serra Bover, postulador de la causa, y D. Vidal González Sánchez visitaron en Roma al Cardenal Saravia Martins, Prefecto de la Congregación para las Causas de los Santos, que repitió varias veces la frase: La Causa de la reina non è fermata, cammina". La causa no está parada, sino que camina"133. Con el nuevo postulador, P. Fernando Rojo, ya se cuenta con un milagro y se aprobarán pronto sus virtudes. En la documentación aportada para el proceso de canonización aparece claramente que estuvo siempre al servicio de Dios y de la Iglesia Católica de Roma a la amó como fiel hija de la misma, según consta en su Testamento, Codicilo y otros escritos suyos ${ }^{134}$.

El lugar, donde nació, está custodiado por las Madres Agustinas, que lo enseñan a los visitantes, resaltando sus virtudes. El Palacio Testamentario, donde murió, se ha declarado "Bien de Interés Cultural" como "Sitio Histórico" por la Junta de Castilla y León el 15 de mayo de 2003. Se cumplió en parte una vieja aspiración formulada por los Caballeros de la Hispanidad y los de Isabel la Católica, que han visto con alegría cómo, el 26 de noviembre de 2003 se inauguraba el Centro de Interpretación de la Reina Católica en el Palacio Testamentario, con una Exposición bien dirigida y organizada. Se

132. CAMPO DEL Pozo, Fernando, "Se reanuda el proceso de canonización de Isabel la Católica" en La Voz de Medina del Campo, Sábado, 16 de marzo de 2002, p. 18. El 31 de diciembre de 2003 fue nombrado postulador el P. Fernando Rojo por el arzobispo de Valladolid. Se aprobó el nombramiento por la Congregación de los Santos el 23 de enero de 2004. El día 30 de enero de 2004 ya tuvo una reunión en Valladolid .

133. Suplemento, n. 8 del BOA, diciembre de 2002, portada, sin paginar. $V$ Centenario. Reina Isabel Católica.

134. Positio super scriptis, pp. 31-33. Así como se han aprobado sus escritos, se espera sean aprobadas también sus virtudes. 
exponen, entre otros valiosos objetos de aquella época, las planchas que contienen los nombres de los 700 medinenses que participaron en la colonización de América, con una réplica del dormitorio, donde testó y murió Isabel la Católica ${ }^{135}$.

Se ha reparado y restaurado el Castillo de la Mota, lo mismo que la Colegiata de San Antolín y el Palacio Testamentario para un Espacio Museográfico de la Reina Isabel y su relación con Medina. Tuvo gran resonancia la exposición Esplendor de un reinado, que se inauguró en la primavera del 2004 en Medina del Campo, con sede también en Valladolid y en Madrigal de las Altas Torres según declaración de la ministra de Educación y Ciencia, D Pilar del Castillo, después de haber presidido el día 16 de octubre de 2003 una reunión de la Comisión Estatal para el V Centenario de la muerte de Isabel la Católica ${ }^{136}$. Las comisiones locales, regionales y nacionales en torno al V Centenario de su muerte se están moviendo para conmemorar digna y solemnemente esta fiesta. Los Caballeros de Isabel la Católica y la Academia de la Hispanidad podemos hacer también un buen aporte para dar realce al $\mathrm{V}$ Centenario de su muerte, colaborando para que la veamos en los altares. Personalmente, como el P. Zacarías Martínez, casi todos los medinenses y vallisoletanos, incluso la mayoría de españoles e hispanoamericanos, tenemos la íntima convicción de que la sierva Isabel goza ya de la bienaventuranza eterna. Conviene movernos y orar con mucha devoción y fe para conseguir que su proceso de canonización siga adelante. Hay estudios serios realizados en estos últimos años ${ }^{137} y$ peticiones de Hispanoamérica en favor de su canonización, como lo resaltó el arzobispo de Valladolid, Mons. Braulio Rodríguez en una conferencia dada en Roma, recordando la evangelización de América ${ }^{138}$. Conviene tener en cuenta que Isabel la Católica en su vida y en su muerte demostró ser fiel hija de la Iglesia Católica.

135. Fuertes, Francis, "Juan Vicente Herrera inauguró el Centro de Interpretación de la Reina Católica", La Voz de Medina y Comarca, 29 de noviembre de 2003, p. 5. Es director D. Óscar S. Pastor Pérez.

136. Martínez Novillo, Álvaro, "Los actos del Centenario de Isabel la Católica arrancarán en Medina del Campo", ABC, n. 32.096, del 17 de octubre de 2003, p. 59. D. Álvaro Martínez Novillo es el director del Instituto del Patrimonio Histórico. La exposición Isabel la Católica, la magnificencia de un reinado se inauguró en la iglesia del monasterio de Prado de Valladolid el 26 de febrero de 2004 con mucho éxito.

137. VAldeón BARUQue, Julio, (ed.) Isabel, la Católica y la política. Ponencias presentadas al I Simposio, celebrado en Valladolid y México, en el 2000, UUniversidad de Valladolid 2001; Sociedad y economía en tiempos de Isabel la Católica, Simposio II, Valladolid 2002 y Arte y Cultura en la época de Isabel la Católica, Simposio III, Valladolid 2003. Hay otras publicaciones muy valiosas.

138. RoDRíGuEZ, Braulio, "Isabel la Católica y la evangelización de América", Ecos monásticos contemplativos, 52 (2003) 11-34. 
$\mathrm{Al}$ celebrarse el V Centenario de su muerte hay que recordar que Isabel estableció una piedra miliaria en Madrigal, con su nacimiento el 22 de abril de 1451, y un hito orientador con su ocaso el 26 de noviembre de 1504, en Medina del Campo. Esto tiene gran repercusión en España e Hispanoamérica. A la hora de su muerte se acordó de los derechos de sus vasallos, incluso los lejanos de las Indias (América). Había cumplido con su deber, como fiel cristiana e hija de la Iglesia, según se lo había expuesto uno de sus principales formadores, fray Martín de Córdoba, que la consideró no sólo legítima heredera de los reinos de Castilla y León sino también la que Dios "predestinó para reina de tan noble reino como España"139. Su unidad en la fe cristiana, exigía la expulsión de los judíos según el mismo Martín de Córdoba, que la preparó para ser "resplandor de castidad y limpieza en todo este reino" 140 . No se puede considerar, "desgraciada decisión" a la expulsión de los judíos en aquella época como lo afirma István Szaszdi León-Borja141. Estuvo justificada y fue tan exitosa como su apoyo al proyecto de Cristóbal Colón. Isabel hizo uso del Patronato con participación en la potestad eclesiástica, algo que sería ampliado en tiempos de su nieto Carlos V y su bisnieto Felipe II con el "Vicariato Regio" defendido por fray Alonso de Veracruz. Esto no es bien visto actualmente a la luz de la libertad religiosa, clarificada en el Concilio Vaticano $\mathrm{II}^{142}$. Hay que ver los acontecimientos y hechos históricos en su lugar y tiempo.

Se trata de una reina digna de los altares. En algunos lugares se la considera venerable y se le ha dado un culto incipiente y solapado, por no decir superpuesto con la Santísima Virgen, en Otengá (Colombia) y en otros lugares de América, de España, de Filipinas, etc. Ella vertebró a España en su época, con su esposo Fernando, y dio origen a lo que luego se ha llamado "Hispanidad". El proceso de canonización sigue adelante. Hubiese ayudado a resaltar el V Centenario de su muerte la deseada canonización, pero hay que esperar y respetar el fallo de la Iglesia, de la que ella se consideró y fue una buena hija, esposa fiel y madre de familia numerosa, como se lo enseñó fray Martín de Córdoba.

\section{Fernando CAMPo del Pozo \\ Medina del Campo \\ Valladolid}

139. Córdoba, Martín de, Jardín de Nobles Doncellas, p. 186.

140. Ibíd., p. 70.

141. León-Borja, I. S., "Prólogo" a Isabel la Católica, por Luis Suárez, p. 9.

142. Declaración sobre la dignidad de la persona humana, 7 de diciembre de 1965, nn. 2-11. 